\title{
Mexico 2017: Incumbent Disadvantage Ahead of 2018
}

México 2017: El gobierno en desventaja rumbo al 2018

\section{EDWIN ATILANO ROBLES}

Centro de Investigación y Docencia Económicas (CIDE), Mexico

\section{ALLYSON LUCINDA BENTON}

Centro de Investigación y Docencia Económicas (CIDE), Mexico

\begin{abstract}
Weak economic performance, high inflation, and a devalued peso drew criticism of the incumbent Institutional Revolutionary Party's (PRI) economic and fiscal policy choices, and kept President Enrique Peña Nieto's approval ratings low. The incumbent PRI thus entered the 2018 electoral season in a weak position, with reduced chances of defeating its main opposition candidate, Andrés Manuel López Obrador, of the National Regeneration Movement (MORENA).
\end{abstract}

Keywords: economic performance, Mexican earthquake, public security, NAFTA, PRI, public opinion, Mexico

\section{RESUMEN}

El débil desempeño, la alta inflación y la devaluación del peso crearon un escenario de críticas hacia las decisiones económicas y fiscales del partido en el gobierno, el Partido Revolucionario Institucional (PRI), y de igual forma facilitaron que el presidente Enrique Peña Nieto tuviera una baja tasa de aprobación. El PRI inició el periodo electoral de 2018 en una posición débil, lo cual redujo sus posibilidades de derrotar al principal candidato de oposición, Andrés Manuel López Obrador, del Movimiento de Regeneración Nacional (MORENA).

Palabras clave: desempeño económico, terremoto mexicano, seguridad pública, TLCAN, PRI, opinion pública, México 


\section{INTRODUCTION}

Ongoing weak economic growth, important social concerns, and deteriorating security conditions during 2017 put the incumbent Institutional Revolutionary Party (Partido Revolucionario Institucional or PRI) at a disadvantage ahead of the 2018 presidential race. Current president Enrique Peña Nieto was elected in July 2012 to a six-year term, with presidential elections held on 1 July 2018. Although term limits prevented Peña Nieto from running for reelection, his PRI naturally sought to retain the national executive. However, weak economic performance, high inflation, and a devalued peso drew criticism of the incumbent government's economic and fiscal policy choices, as well as kept Peña Nieto's approval ratings low. The government's response to the 19 September 2017 earthquake, ongoing corruption scandals, and deteriorating security conditions also hampered government popularity, with Peña Nieto holding the dubious distinction of being one of the most unpopular Mexican presidents in the past 20 years. The PRI thus entered the 2018 electoral season in a weak position, with reduced chances of defeating its main opposition, the left-leaning former Mexico City mayor and three-time presidential candidate Andrés Manuel López Obrador, who prevailed.

\section{ECONOMIC ENVIRONMENT}

Shortly after taking office on 1 December 2012, the Peña Nieto administration unveiled a series of structural economic reforms designed to raise economic efficiency (Barrientos del Monte and Añorve Añorve 2014). ${ }^{1}$ Although some of the reforms began to pay off in 2017 (Organization for Economic Cooperation and Development 2017), with the Mexican economy showing some signs of life later in the year (Guzmán Calafell 2018), much of the economic news during 2017 was negative. From a political standpoint, any delays in the benefits accrued from economic reforms stood to undermine the incumbent government's electoral prospects in 2018.

Specifically, the Mexican economy was plagued by slow growth in 2017. Slow US economic growth in 2015 and 2016 is partly to blame for Mexico's weak 2017 economic performance, with the effects of the 2015/2016 US slowdown lingering in Mexico into 2017. Also, the increasing likelihood that Donald J. Trump would win the November 2016 US presidential race further weakened the performance of the Mexican economy. Trump claimed that he would

\footnotetext{
The most important were reforms to labor, tax, energy, and telecommunications regulations (Barrientos del Monte and Añorve Añorve 2014; Organization for Economic Cooperation and Development 2017). Labor reforms aimed to make it easier to hire/fire workers, to help raise employment in the formal sector. Tax reforms aimed to simplify and plug loopholes in the nation's tax codes, in order to improve collections. Energy reforms aimed to open both the hydrocarbons and electricity sectors to private investment, increase investment, and reduce prices. Telecommunications reforms aimed to deregulate the industry and improve investment and lower prices.
} 
stem illegal immigration and build a border wall, something that threatened remittances from Mexican migrants (Time 2015; Trump 2015). Trump also claimed that he would renegotiate the North American Free Trade Agreement (NAFTA), scrapping the agreement should the US not receive favorable terms, thereby threatening Mexican exports (Time 2015; Trump 2015). This raised investor concerns about the future health of the Mexican economy.

Mexican economic growth rates shrank from 2.7 in 2016 to 2.3\% in 2017, with much of low growth during 2017 due to weak mid-year performance (Figure 1). Although the Mexican economy showed some signs of recovery toward the end of 2017, it was not sufficient for pushing overall growth beyond 2016 levels (Guzmán Calafell 2018). US economic and political dynamics also accounted for Mexico's sluggish gross fixed investment and falling industrial activity rates, a trend which began in 2015 but carried well into 2017 (Guzmán Calafell 2018). Both gross fixed investment and industrial activity were stagnant from 2015 into 2017, although they showed some signs of recovery toward the end of the year (INEGI n.d.; Banco de México n.d.). See the appendix for relevant figures.

Interestingly, despite weak economic growth, unemployment-whether measured as unemployed, partially unemployed, or underemployed-declined in 2017 compared to 2016 (Guzmán Calafell 2018; INEGI n.d.). Labor and tax reforms that streamlined hiring/firing processes and tax codes (OECD 2017) encouraged job creation, amidst slow growth. The nation's service sector, as shown in Figure 2, enjoyed the most significant job creation. The service sector accounts for about $60 \%$ of overall GDP, compared to the industrial sector's $35 \%$ of GDP, and the agricultural sector's 5\%. Despite being a major part of the Mexican economy, however, strong service sector performance was not enough to compensate for the nation's weak gross fixed investment and industrial activity.

It is important to note that several economic factors offset the impact of any employment gains on domestic consumption and thus the nation's economic performance. First, most new job creation appears to have been in the form of part-time employment. Second, the nation remained plagued by high poverty rates (OECD 2017). The proportion of the population living in poverty shrank by $3.5 \%$ in 2017 but about half (43.6\%) of the population still lives in poverty (Animal Político 2017c). Income remains highly concentrated, with the wealthiest $20 \%$ of the population earning 10 times more than the poorest $20 \%$. The poverty rate in Mexico is twice as high as that of the average for OECD nations (OECD 2017).

Third, inflation rose significantly in 2017, well above the central bank's (Banxico) 3\% +/- 1\% target rate (Figure 3) (Banco de México 2018). Peso depreciation and rising prices on consumer goods raised inflation (Guzmán Calafell 2018). Of course, the government's deteriorating debt-to-GDP ratio has been largely responsible for peso depreciation over the past 10 years, as shown in Figure 5. However, although Mexico's fiscal deficit was only 1.1\% of GDP in 2017 
(Figure 4), fiscal deficits contributed a dramatic rise in total public debt loads during the Peña Nieto administration, weakening investor confidence in the government's fiscal health and thus in the value of the peso. The November 2016 US presidential election and victory of Donald J. Trump further weakened the peso (Banco de México 2018).

Figure 1. Economic Growth in Mexico

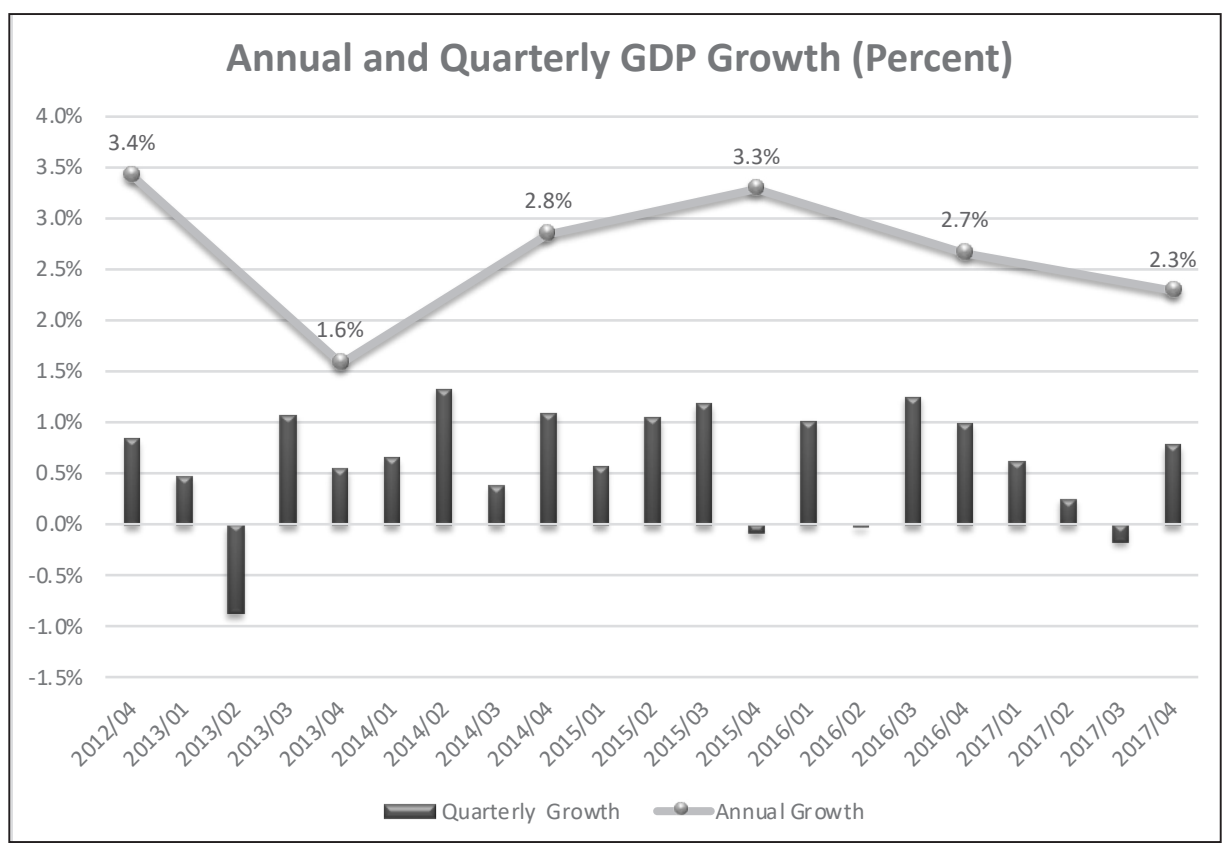

Source: INEGI n.d. 
Figure 2. Unemployment in Mexico

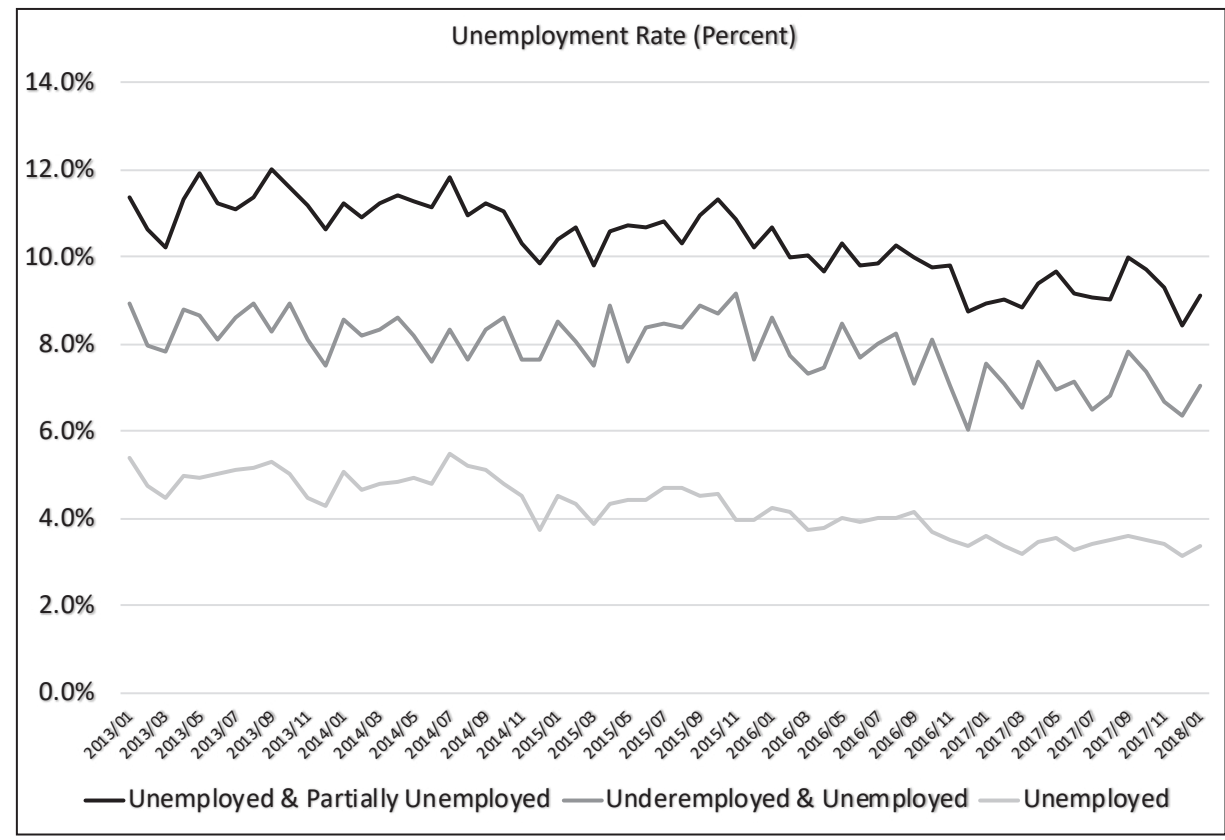

Source: INEGI n.d.

Figure 3. Inflation in Mexico

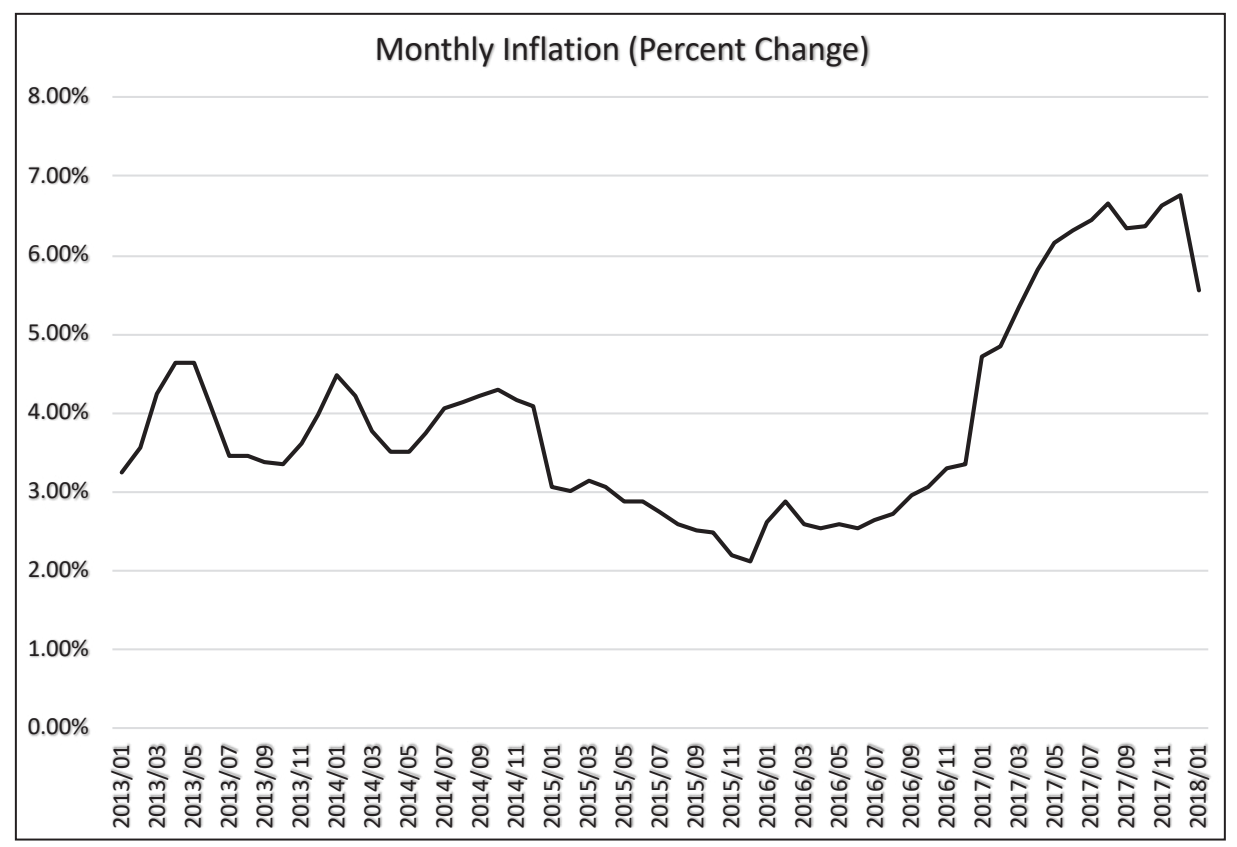

Source: Banco de México n.d. 
Figure 4. Annual Fiscal Deficit

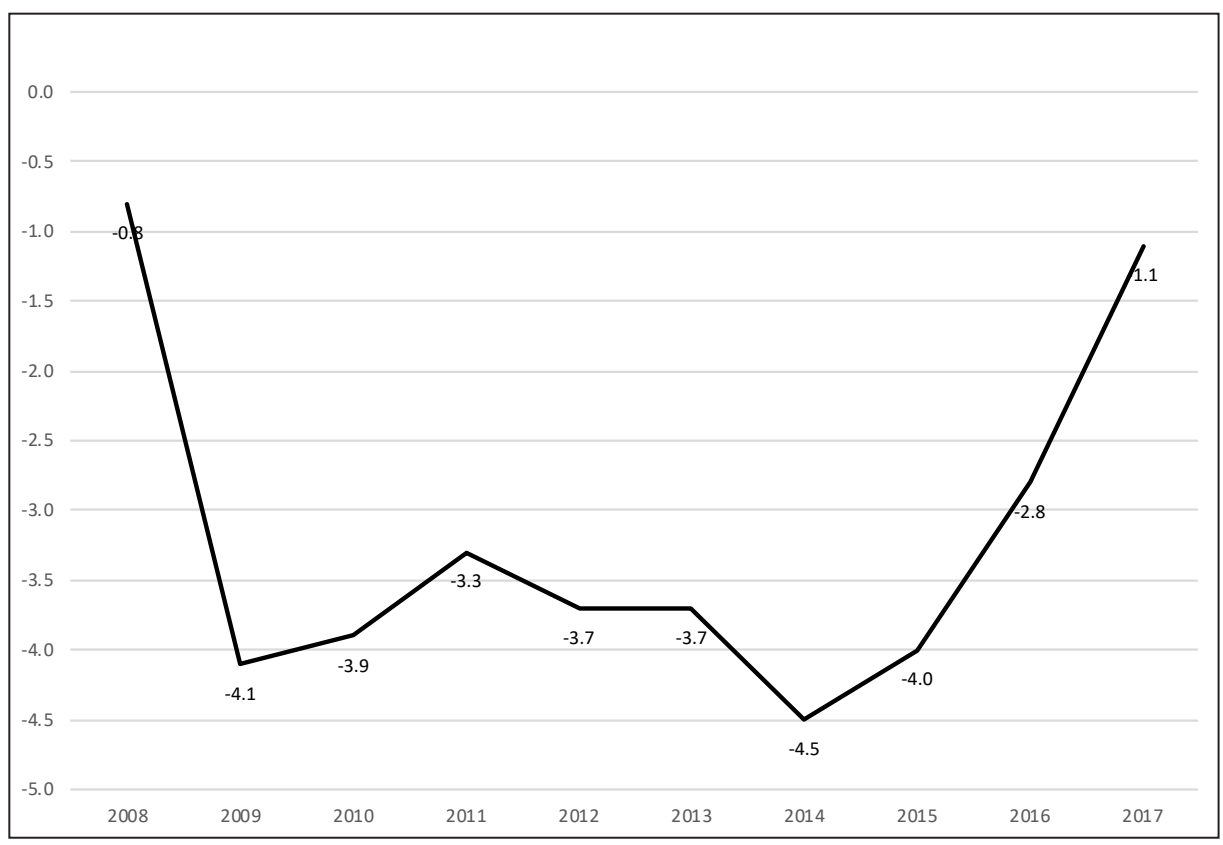

Source: INEGI n.d.

Figure 5. National Public Debt and Peso Depreciation

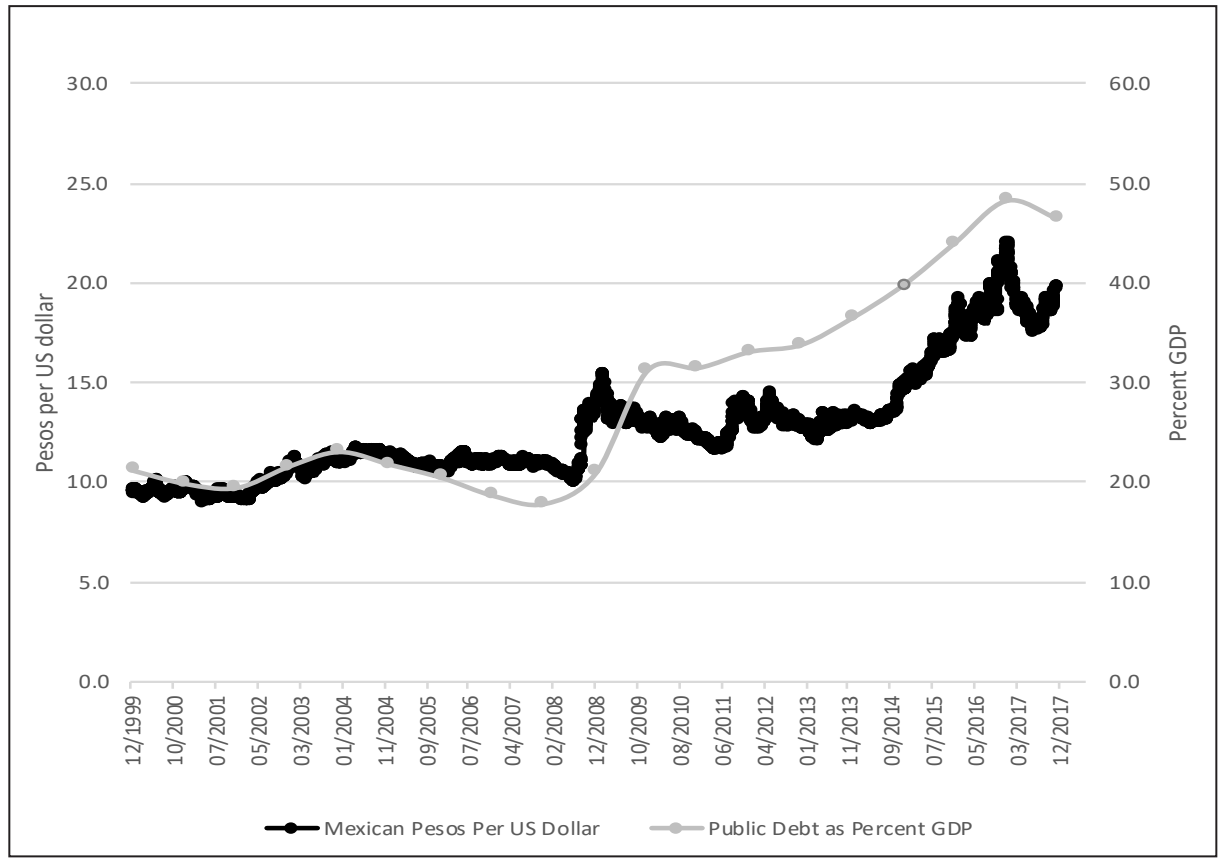

Source: INEGI n.d. 
Ongoing peso depreciation continued to make the cost of imports-including both imported goods and services as well as imported inputs into the Mexican production process-more expensive, thereby raising domestic prices. Rising energy prices due to global oil price recoveries (Guzmán Calafell 2018) not only raised the price of household energy consumption, but also the prices of domestic goods and services. Meanwhile, real wage growth remained slow in 2017, despite minimum wage adjustments during 2017 (Gillespie 2017). Many voters experienced rising household expenditures that were equal to or outpaced wage adjustments, with their purchasing power remaining stagnant or deteriorating in 2017 (Animal Político 2017b; Gillespie 2017).

Poor economic growth amidst stagnant (or declining) household purchasing power raised criticism of the government's economic policy reforms. Politicians from the right-leaning National Action Party (Partido Acción Nacional or PAN) argued that the government's structural economic reforms failed because they did not go far enough and/or were not effectively implemented. Politicians from the left-leaning National Regeneration Movement (Movimiento de Regeneración Nacional or MORENA) argued that the government's neoliberal economic policy approach failed and advocated for a greater role of the state in the economy. Politicians from these parties have also been critical of the government's fiscal policy management. The government undertook fiscal austerity measures in reaction to stagnant fiscal revenues, in order to appease credit ratings agencies, noting that ratings downgrades would raise the cost of debt financing. However, opposition politicians argued that the government's fiscal austerity has been more rhetorical than real (Animal Político 2016). Government revenues have increased over the years (Guzmán Calafell 2018), but with the government still running fiscal deficits — even if shrinking ones — that contributed to rising debt-toGDP levels (Animal Político 2016) and downward pressure on the peso (Figure 5).

Although most politicians criticized the national government for its fiscal deficits and rising public debt, subnational fiscal deficits and rising debt loads were also a point of concern. As shown in Figure 6, subnational public debt continued to rise in 2017, despite reforms to the Law of Financial Discipline in Federal States and Municipalities (Ley de Disciplina Financiera de las Entidades Federativas y los Municipios) aimed at regulating and reducing state and municipal debt that same year. Among other things, the law aimed at establishing debt limits, gauged to fiscal resources, across all states and municipalities, which were originally established by state governments on a state-by-state basis. The law also clarified the authorized uses for long-term debt (for public investment and refinancing), as well as the authorized uses for short-term debt (for year-end bridge loans to meet year-end payments). Lack of clarification on these fronts in prior legislation had led to the use of both long-term and short-term debt for financing current expenditures.

Both total and per capita state and municipal debt rose in peso terms during 2017 , although the debt share as a percent of national GDP and as a percent of unearmarked federal transfers declined somewhat, as shown in Figure 6. In 
four states, namely Nuevo León $(13,600)$, Quintana Roo $(13,400)$, Chihuahua $(13,200)$, and Coahuila's $(12,100)$, per capita debt far exceeded that of other states (Centro de Estudios de las Finanzas Públicas (CEFP) 2018). These four states also posted debt as a percent of unearmarked federal transfers above $200 \%$ (Nuevo León: 213\%; Quintana Roo: 232\%; Chihuahua: 223\%; and Coahuila: 212\%), followed by Sonora (145\%), Veracruz (126\%), and Mexico City (123\%) (Centro de Estudios de las Finanzas Públicas (CEFP) 2018). Notably, much of the debt in these four states was accrued under state-level PRI rule, which resulted in recent partisan turnover, specifically an independent candidate in Nuevo León, and PAN-PRD (Partido de la Revolución Democrática or Party of the Democratic Revolution) coalition candidates in Quintana Roo 2016 and Chihuahua 2016. The PRI survived in Coahuila, but in a weakened state, as described below. High state and municipal indebtedness threaten subnational governments' capacity to meet public policy obligations, something that can threaten citizens' wellbeing and political support.

Figure 6. Total State and Municipal Debt

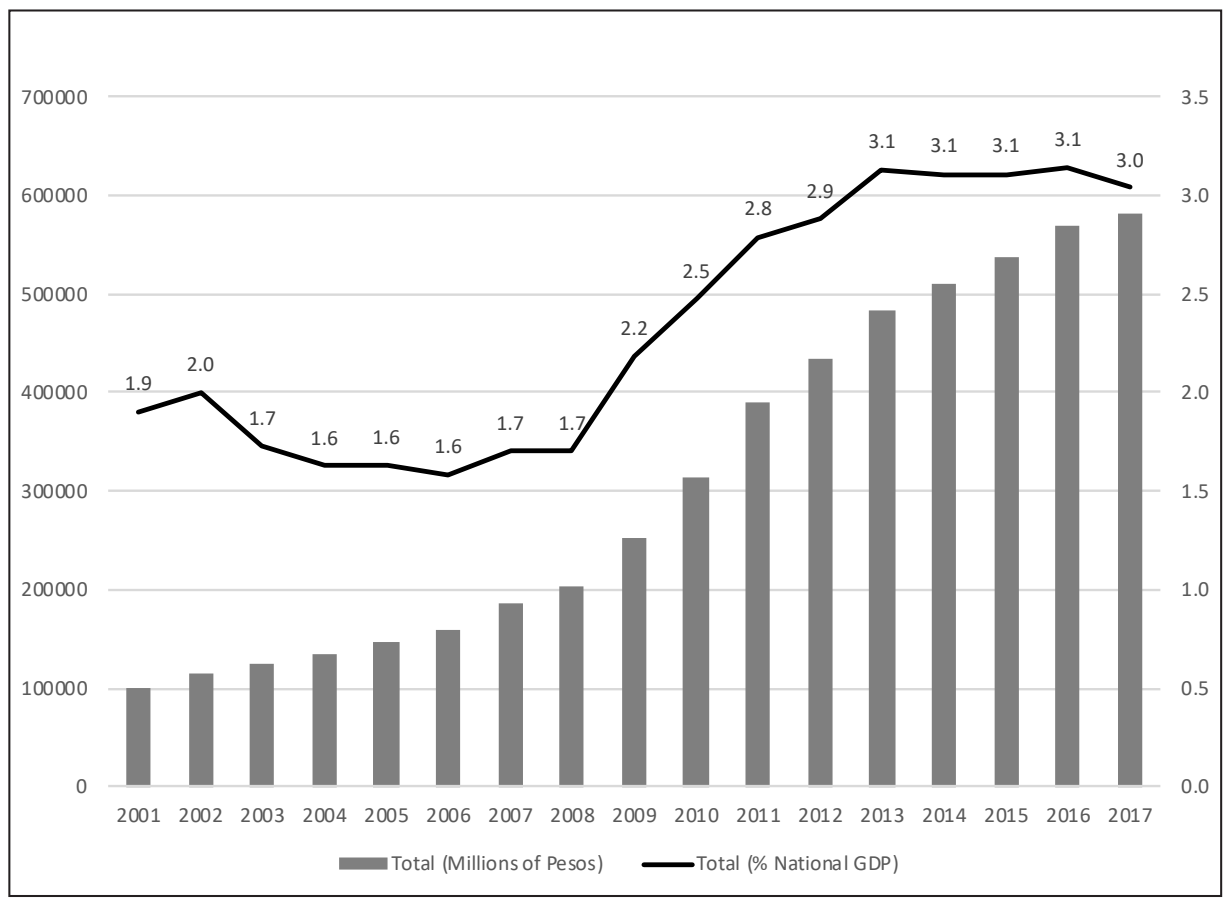

Source: Secretaría de Hacienda y Crédito Pública (SHCP) 


\section{SOCIAL ENVIRONMENT}

Social conditions also combined with weak economic performance to undermine public attitudes toward the PRI during 2017 and in the run up to the 2018 presidential election.

On 1 January 2017, the Finance Ministry (Secretaría de Hacienda y Crédito Público) began to liberalize gasoline prices in order to move from the traditional government-determined price setting mechanism to a market-determined pricing system. This process began with a $14 \%$ increase in 87 octane gasoline prices and 20\% increase in 92 octane gasoline prices, effective until 3 February 2017 when bi-monthly increases occurred until domestic prices were in line with international ones (Daen and Padilla 2017). Although the government's objective was to reduce the fiscal impact of energy price subsidies, as well as to support deregulation in the energy sector to increase investment, the effect of price rises was negative for citizens. Protests at gas stations and blockades of major highways occurred throughout the nation in response, with some resulting in violence (Daen and Padilla 2017). About 300 stores were looted, although most looting was concentrated in Mexico City and the states of Mexico and Veracruz. In response, the Mexican government arrested about 250 people accused of theft and vandalism during the protests (Sholchet 2017).

The nation's security situation also worsened during 2017, with homicide rates that year making it the most violent year since 1997, when national homicide figures were first recorded. There were 25,339 intentional homicides in 2017, with the official homicide rate reaching 20.5 per 100,000 persons (Secretariado Ejecutivo del Sistema Nacional de Seguridad Pública 2018). By comparison, in 2016 there were 20,547 homicides, with a homicide rate of 20.16 per 100,000 persons (Secretariado Ejecutivo del Sistema Nacional de Seguridad Pública 2018). See Figure 7 and Table 1. Growing homicide rates, alongside other types of violent crime, raised citizens' feelings of insecurity in their states, cities, and neighborhoods, as shown in Figure 8. Voters' rising sense of insecurity further played against the national incumbent PRI, although voters also blamed state and municipal governments for the security situation as well. 
Figure 7. Homicides in Mexico, 1997- 2017

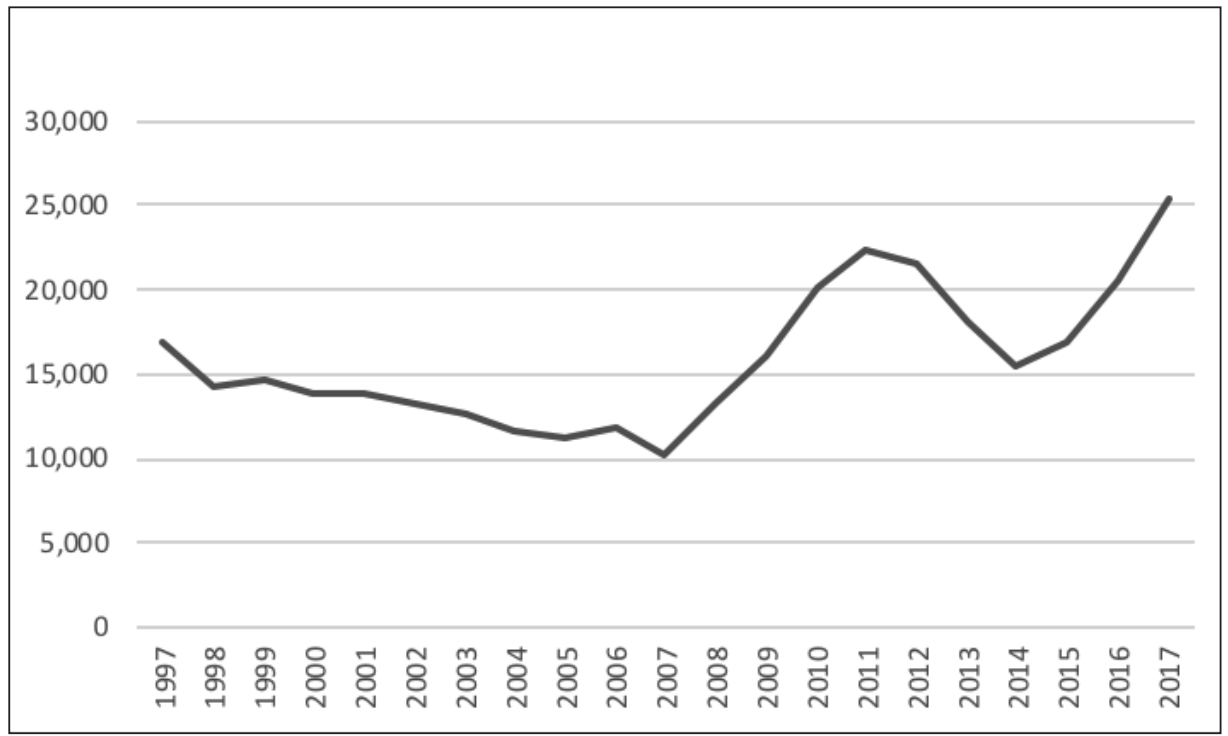

Source: Secretariado Ejecutivo del Sistema Nacional de Seguridad Pública (2018)

Table 1. Rate of Homicides Per 100,000 Persons Per State (2017)

\begin{tabular}{lc}
\hline \multicolumn{1}{c}{ StATE } & $\begin{array}{c}\text { RATE OF } \\
\text { HoMicidEs }\end{array}$ \\
\hline Aguascalientes & 6.21 \\
Baja California & 58.28 \\
Baja California Sur & 75.32 \\
Campeche & 7.06 \\
Chiapas & 8.86 \\
Chihuahua & 41.41 \\
Coahuila & 7.33 \\
Colima & 93.94 \\
Ciudad de México & 11.89 \\
Durango & 12 \\
Guanajuato & 18.35 \\
Guerrero & 64.26 \\
Hidalgo & 6.24 \\
Jalisco & 16.55 \\
Estado de México & 11.70 \\
Michoacán & 27.05 \\
\hline
\end{tabular}




\begin{tabular}{lc}
\hline \multicolumn{1}{c}{ STATE } & $\begin{array}{c}\text { RATE OF } \\
\text { HoMicides }\end{array}$ \\
\hline Morelos & 29.25 \\
Nayarit & 19.95 \\
Nuevo León & 11.72 \\
Oaxaca & 20.85 \\
Puebla & 14.16 \\
Querétaro & 8.53 \\
Quintana Roo & 21.57 \\
San Luis Potosí & 16.10 \\
Sinaloa & 41.19 \\
Sonora & 24.14 \\
Tabasco & 15.96 \\
Tamaulipas & 22.19 \\
Tlaxcala & 9.14 \\
Veracruz & 19.13 \\
Yucatán & 1.70 \\
Zacatecas & 34.43 \\
\hline
\end{tabular}

Source: Secretariado Ejecutivo del Sistema Nacional de Seguridad Pública (2018)

Figure 8. Insecurity Perceptions in Mexico

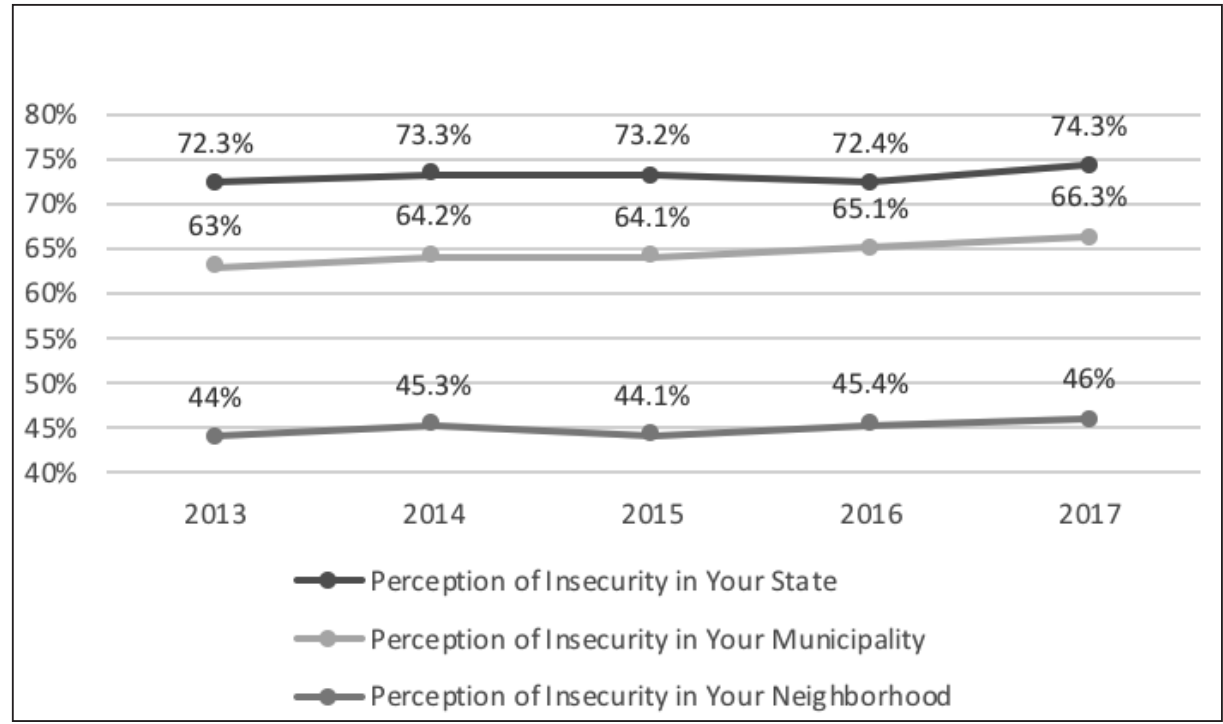

Source: Instituto Nacional de Estadística y Geografía (INEGI) (2017) 
Two major earthquakes in 2017 further marred Mexico's national mood. The first earthquake occurred on 7 September, with a magnitude of 8.2 on the Richter scale and epicenter 137 kilometers southwest of Pijijiapan, Chiapas. The Civil Protection Ministry (Protección Civil) in Chiapas reported a total of 80,508 homes affected, of which 22,340 were totally destroyed. Other nearby states suffered damages as well, including an explosion at an oil refinery in Salina Cruz, Oaxaca, damages to about 250 homes in Veracruz, and ground cracks and sinking in Tabasco. The second earthquake occurred on 19 September-32 years to the day of the 1985 earthquake which devastated Mexico City that year-with a magnitude of 7.2 degrees and epicenter near San Felipe Ayutla, Puebla. In Mexico City, more than 44 buildings collapsed, and thousands were evacuated until they could be examined (Pskowski and Adler 2017). A total of 369 fatalities were reported, with 228 in Mexico City, 74 in Morelos, 45 in Puebla, 15 in Mexico state, six in Guerrero, and one in Oaxaca (Ureste and Aroche 2017). The 19 September 2017 earthquake damaged 5,765 homes, with 40\% of these rendered uninhabitable, in Mexico City alone. The Ministry of Public Education (Secretaría de Educación Pública) reported that there were 16 thousand schools damaged in ten states, with 1,208 of these in Mexico City. Similarly, 53 hospitals also suffered serious damage, and a further 325 suffered minor damage. The earthquakes left over 6 million people in Puebla, Morelos, and Mexico City temporarily without drinking water as well (Ureste and Aroche 2017). The government estimates that the two earthquakes together affected over 12 million people in 400 municipalities (Ureste and Aroche 2017).

Surprisingly, the damage from the earthquakes did not negatively impact the Mexican economy. Indeed, the reverse was true: reconstruction efforts, including public and private expenditure, helped trigger economic activity in the affected areas, likely contributing to Mexico's improved fourth quarter economic growth rates (Casillas 2017). Also important, the Mexican government's response was widely lauded internationally, something that reflected well on the national government (Casillas 2017). The government organized a timely response from relevant national institutions and ministries and their subnational counterparts. It drew upon its special disaster fund for reconstruction (Fideicomiso Fondo de Desastres Naturales or Fonden). The national government also facilitated the delivery international monetary aid from places like Andorra, Canada, China, Korea, France, United States, Taiwan, and even the Vatican, as well as the incorporation of technical support from Germany, Japan, Switzerland, the United Nations, and the European Union into the search and rescue and other recovery efforts (Ureste and Aroche 2017). Various images demonstrating international and domestic solidarity with those affected by the earthquakes emerged, with the navy search and rescue dog Frida becoming a world-recognized symbol (Ureste and Aroche 2017).

Yet, two things colored the public's mood in the aftermath of the earthquakes: the damage to new construction that revealed deep corruption in government building code enforcement, and the apparent efforts by parties to use the 
earthquake to raise their public image ahead of the 2018 presidential race (Casillas 2017). Shortly after the 19 September earthquake, newspaper reports began to circulate noting the thousands of building code violation complaints that had been lodged with Mexico City authorities over the years, with 1,271 complaints filed in 2016 alone (Pskowski and Adler 2017). These included complaints about poor quality or outdated building materials, insufficient foundational and structural supports, numbers of building floors in excess of code limits, unauthorized rooftop construction of things like roof gardens, solar panels, and helipads, as well as engineers guiding and architects designing projects despite having expired licenses (Associated Press 2017; Pskowski and Adler 2017; Ahmed, Franco, and Fountain 2017). Official building inspectors responsible for building code enforcement and the investigation of violation complaints often had false or expired credentials as well (Pskowski and Adler 2017; Ahmed, Franco, and Fountain 2017). Although most public criticism and outrage was appropriately targeted at Mexico City officials, these revelations contributed to the public's sense of worsening government corruption and legal impunity, something already coloring public views.

Unsurprisingly, public opinion polls show that $43 \%$ of citizens in states affected by the earthquakes (Mexico City, Chiapas, Morelos, Oaxaca, and Puebla) evaluated the national government's performance during the disaster as very bad or bad, compared to $35 \%$ who evaluated its performance as very good or good. See Figure 9. State governments also suffered from poor evaluations, with $40 \%$ of people polled ranking their performance as very bad or bad, compared to $36 \%$ who ranked their performance as very good or good. In contrast, the nation's armed forces as well as its Civil Protection ministries were rated much higher.

Figure 9. Government Performance During the 2017 Earthquakes

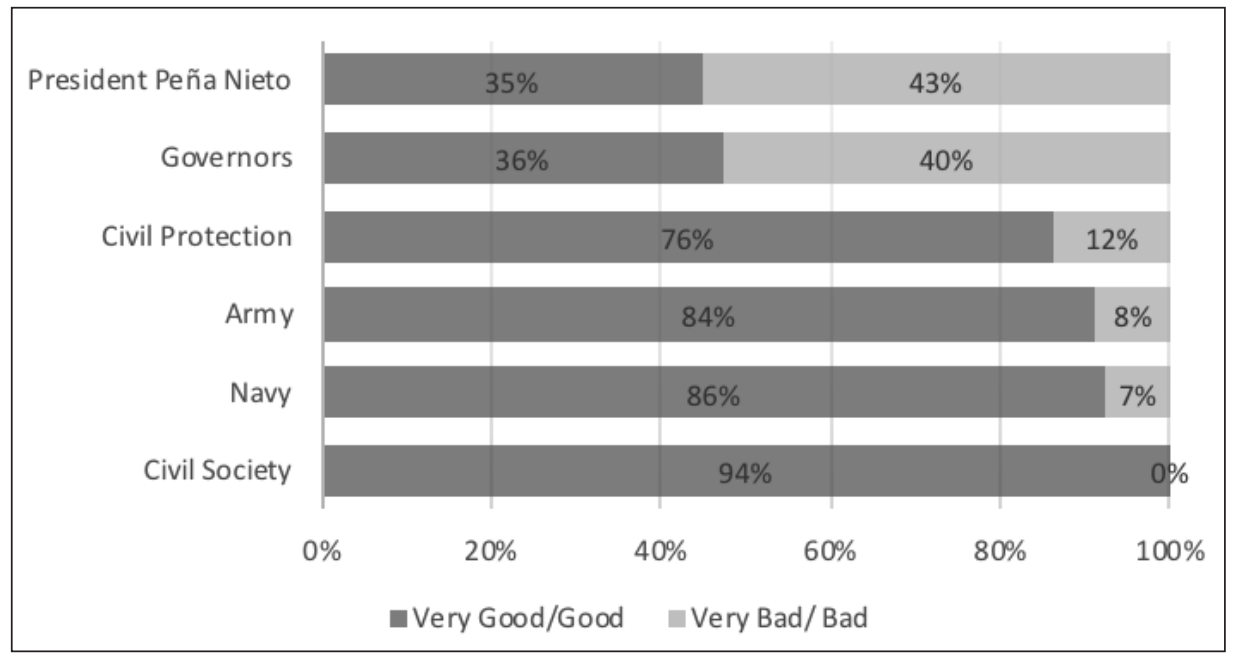


Under increased political scrutiny and public pressure after these revelations, the nation's political parties agreed to "donate" party funds, earmarked for "ordinary party activities," to reconstruction efforts in the affected states. The Institutional Revolutionary Party (PRI) donated three months of its public financing (October, November and December), for a total 258 million pesos. The PAN donated two months (November and December), for a total of 50 million pesos (Nación 321). The Green Party (Partido Verde Ecologista de México or PVEM) donated three months, for a total of 10.5 million pesos. The MC party donated about 51 million pesos (Nación 321). The PRD donated about 25 million pesos (Nación 321). In contrast, MORENA and the Labor Party (Partido del Trabajo or PT) claimed that they would create a trust, to be administered by MORENA, with the money sent directly to those affected, although there is no official data on the funds deposited to or spent by this trust (Nación 321). Because Mexico's parties are financed with public resources, it was difficult for them to claim credit for their "donations," with much of the public still viewing these "donations" as a political strategy designed to improve their profiles ahead of the July 2018 presidential election.

\section{NATIONAL POLITICAL ENVIRONMENT}

The arrest of four former PRI governors in 2017 aggravated the negative impact of the events described above on citizens' views about the incumbent national government. Tomás Yarrington, former governor of Tamaulipas (1999-2005), is accused by the US Drug Enforcement Agency (DEA) of laundering millions of dollars for the Zetas and the Gulf Cartel (González and Reyes 2017). He was arrested on 9 April 2017 in Florence, Italy. Eugenio Hernández, Yarrington's successor (2005-2010), was arrested in October 2017 in Mexico and is accused of embezzlement and money laundering (Diaz 2017). Roberto Borge, former governor of Quintana Roo (2011-2016), was arrested in June 2017 in Panama boarding a flight to Paris. He is accused of embezzlement and illicit enrichment (Diaz 2017). Javier Duarte, former governor of Veracruz (2010-2016), is accused of corruption and diverting public resources (Animal Político 2017a). His administration is notorious for paying out 431 million pesos to at least 41 phantom companies, with millions of pesos in cash, works of art, and other goods acquired by Duarte and his spouse discovered in storage. Duarte was captured on 15 April 2017 in Guatemala and extradited to Mexico on 4 July 2017 (Animal Político 2017a).

Although these arrests testified to the national PRI's willingness to investigate and prosecute its members' worst misdeeds, the levels of corruption occurring in Mexico in recent years appear unprecedented (Malkin 2017). They also come on the heels of a series of other state level corruption scandals that have not been adequately investigated by the national incumbent administration (Agren 2017; Diaz 2017; Malkin 2017), as well as on the heels of two other scandals directly affecting Peña Nieto himself. In November 2014, a group of reporters 
revealed that Peña Nieto's wife, Angélica Rivera, a former soap opera actress, had purchased a multi-million-dollar mansion that had been built and financed by a major construction company competing for state and federal public works contracts (Freidenberg and Aparicio 2016). Claiming that there was no legal wrongdoing, Peña Nieto admitted in July 2016 that public misperceptions about the construction and sale of the property had damaged the office of the presidency. The apology was widely rejected by the public as non-credible (by $69 \%$ ), as most citizens already believed that the property was not acquired in accordance to law (Reforma 2016). Additional revelations later surfaced in August 2016 about another property, a luxury apartment in Miami, purchased by Rivera but whose property taxes were being paid by a businessman and personal friend of the president (de Córdoba and Pérez 2016).

Needless to say, Transparency International reported a decline (equivalent to an increase in corruption) in its Corruption Perception Index (CPI) for Mexico in 2017. The CPI index captures national corruption through measures of open government, accountability, freedom of expression, transparency, public servant integrity, and access to justice. It ranges from 0 to 100, with 0 being the worst ranking (highest corruption) and 100 the best (lowest corruption). Of the 180 countries included in the index, Mexico was ranked 135th, among the worst offenders and alongside countries such as Honduras, Paraguay, Russia, and Kyrgyzstan (Transparency International). As shown in Figure 10, the CPI has declined (corruption has increased) throughout the Peña Nieto administration, falling yet again in 2017 .

Figure 10: Mexico's Corruption Perception Index

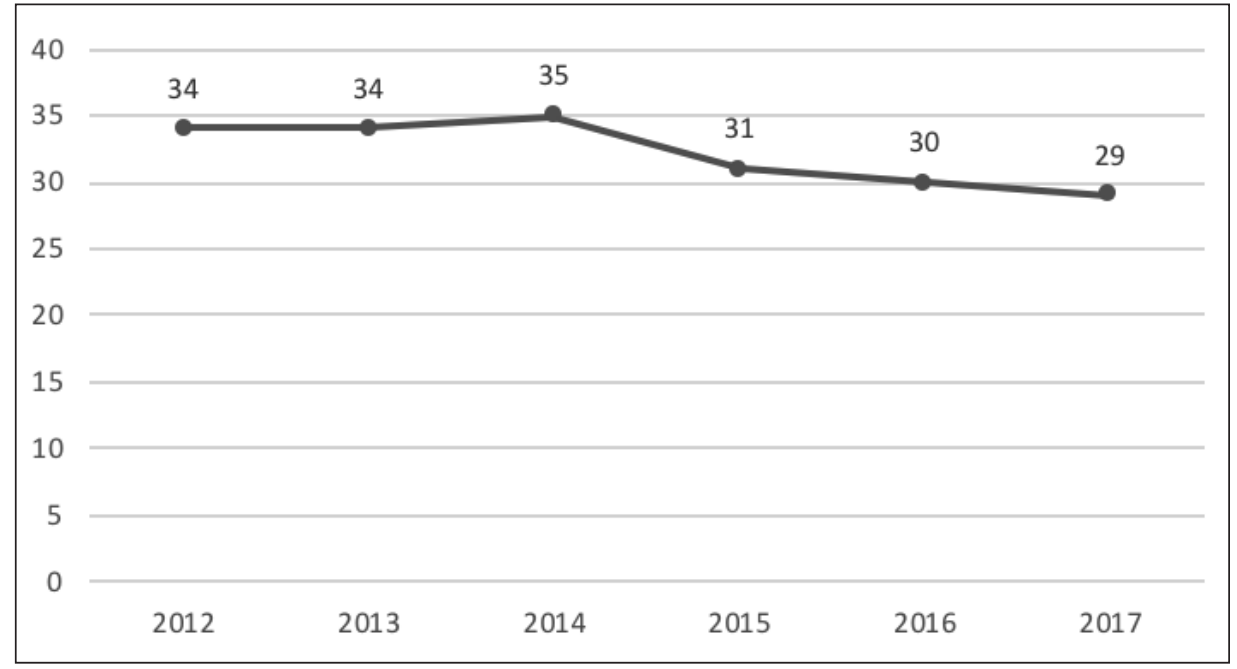

Source: Transparency International n.d. 
Peña Nieto thus retained the dubious distinction of being the most unpopular president in Mexico since the Mexican government first began recording presidential popularity in the 1990s (Linthicum 2016). Even so, Peña Nieto enjoyed a slight increase in approval ratings toward the end of the year, going from $17 \%$ approval in February to $26 \%$ by the end of the year (Figure 11). This was likely the result of improving economic conditions and Peña Nieto's increasingly hard line against US President Donald J. Trump in negotiations of the North American Free Trade Agreement (NAFTA). Even so, fewer than three out of ten Mexicans approved by the Peña Nieto administration in late 2017.

Figure 11. Presidential Approval

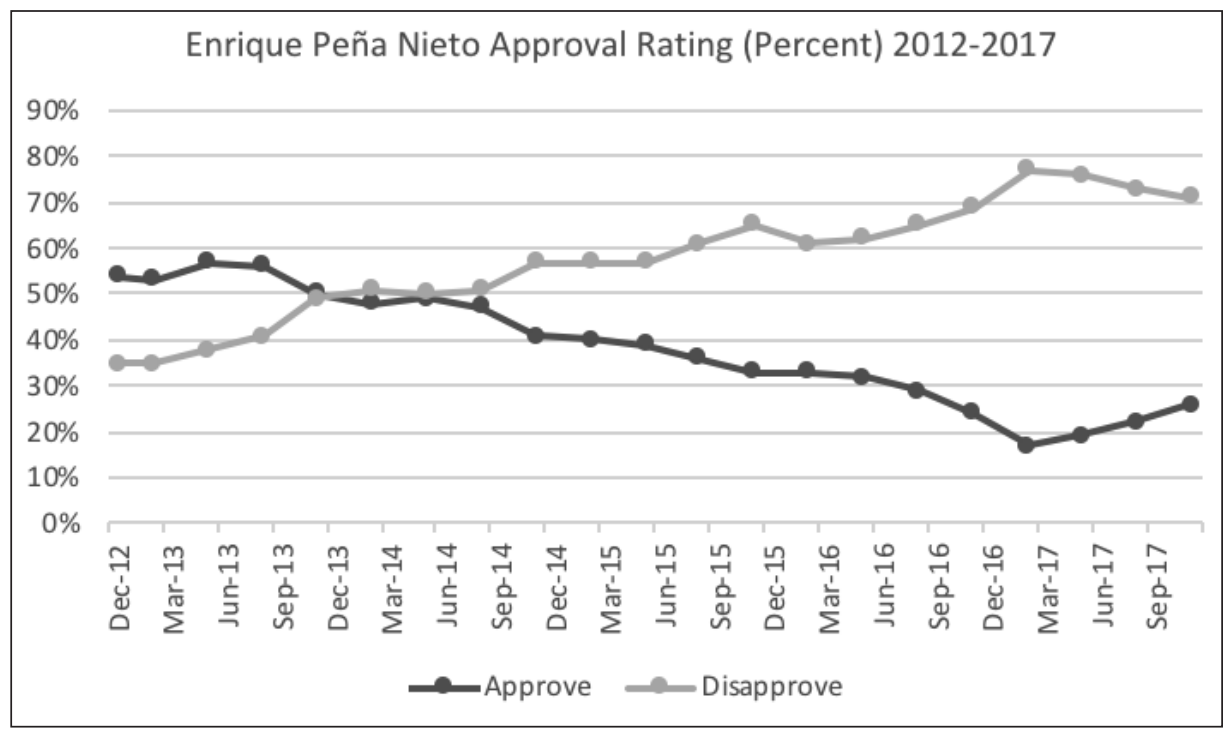

Source: Consulta Mitofsky (2018)

It was amidst a political environment stacked against the PRI that Mexico's political parties began to strategize their presidential candidate selection for the 1 July 2018 presidential race. The ruling PRI's main presidential hopefuls included Education Minister Aurelio Nuño, Finance Minister José Antonio Meade, Health Minister José Narro, and Interior Minister Miguel Ángel Osorio Chong. However, PRI statutes limited presidential candidates to those having been party members for at least 10 years. To allow Nuño and Meade to join the field, the PRI held a party assembly in August 2017 to change its rules. Meade-a longtime technocrat serving both PAN and PRI administrationswas eventually chosen to head the party's coalition ticket, with his selection formalized by a party convention in February 2018. Nuño became Meade's campaign chief. The ruling PRI joined in coalition with its longtime partner, the PVEM, as well as with the New Alliance party (Nueva Alianza or NA), in 
what was formally called the "Everyone for Mexico" (Todos por Mexico) coalition (Reséndiz 2018). The PRI's hope was that Meade, a well-known technocrat without prior affiliation with the PRI, would be less tarnished by the incumbent government's poor approval ratings (Cattan 2017).

The right-leaning PAN's main presidential hopefuls were party president Ricardo Anaya, Margarita Zavala, wife of former president Felipe Calderón (2006-2012), and former governor of Puebla Rafael Moreno Valle (2011-2017). Ricardo Anaya was eventually selected to head up a coalition between the PAN, the left-leaning PRD, and the MC party, called "For Mexico in Front" (Por México al Frente), in February 2018 (Montes, Flores, and Brito 2018). The PRI-PRD-MC coalition was highly criticized by party members, despite this same coalition having been successful in several prior gubernatorial elections, such as Oaxaca (2010), Veracruz (2016), and Nayarit (2017). As a result, both parties suffered internal splits. In the PAN, the proposal that Anaya should be the coalition's candidate resulted in the renouncement of Margarita Zavala of her party membership and her intention to run as an independent candidate. Several national senators close to former president Calderón also resigned, including Ernesto Cordero, Roberto Gil Zuarth, and Luisa María Calderón. Senator Javier Lozano also resigned from the PAN but joined the Meade (PRI-PVEM-NA) campaign. In the PRD, several members renounced their party membership and joined the campaign of Andrés Manuel López Obrador from MORENA. For example, Senator Dolores Padierna, Senator Miguel Barbosa, former PRD Presidents Pablo Gómez and Leonel Godoy, as well as deputy Víctor Hugo Romo broke from the PRD and joined MORENA, placing PRD survival after the 2018 election in jeopardy (Guzmán and Gutiérrez 2017).

The left-leaning MORENA candidate was former Mexico City mayor and former PRD presidential contender Andrés Manuel López Obrador. MORENA was joined by the PT and Social Encounter (Encuentro Social or ES) in the "Together We Will Make History" coalition (Juntos Haremos Historia). López Obrador resigned as MORENA party president and registered as the coalition's candidate in December 2017 (García and Zavala 2017).

Among all candidates, López Obrador was best able to leverage the government's poor economic performance and corruption scandals to his advantage. He also drew a direct link between the PRI's structural economic reforms-approved with the support of the PAN-and the nation's poor economic performance and ongoing high poverty rates. López Obrador was also best able to capitalize on the incumbent government's restrained reactions to US President Donald J. Trump's negative comments about Mexico during 2017 (Foer 2017). As shown in Figure 12, although Anaya (PAN) enjoyed an early lead in pre-election polls, he was surpassed by López Obrador (MORENA) later on, with the PRI trailing in most polls. 
Figure 12. 2018 Presidential Vote Intentions

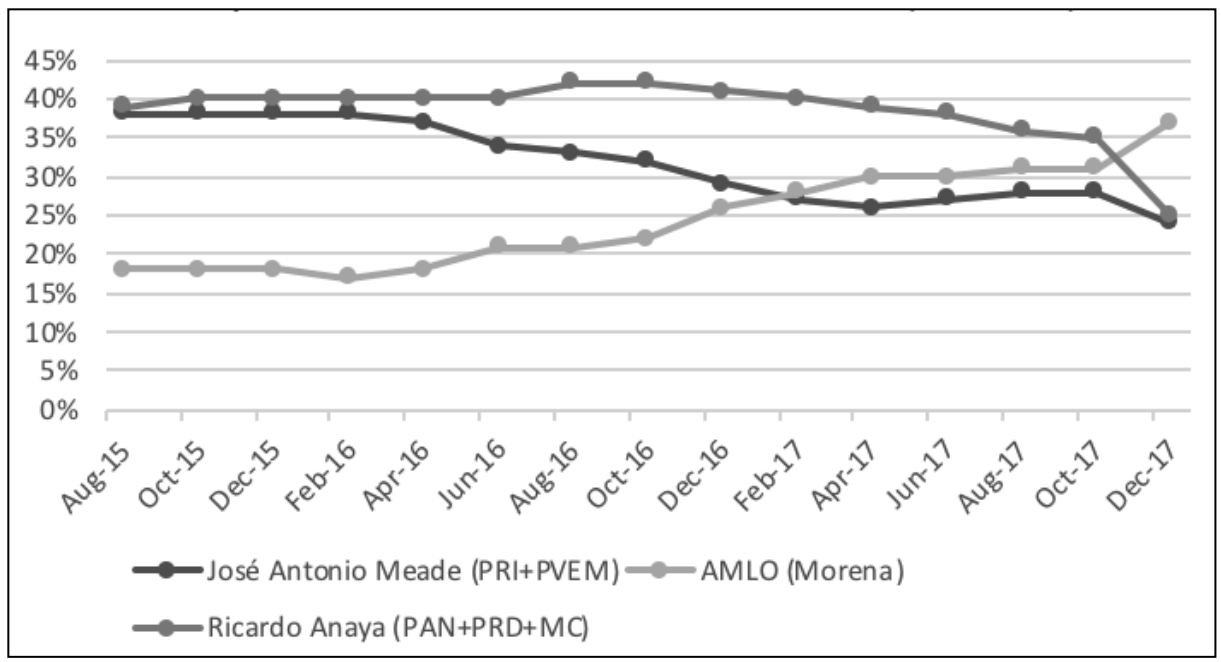

Source: Márquez (2018)

\section{SUBNATIONAL POLITICAL ENVIRONMENT}

Subnational elections occurred in four states on 4 June 2017: Coahuila (state governor/legislature; municipal mayors/councils), Mexico (state governor), Nayarit (state governor/legislature; municipal mayors/councils), Veracruz (municipal mayors/councils). State and local elections serve as an important indicator for subsequent presidential elections, especially those occurring in the year prior to the race. On balance, the national ruling PRI achieved only mixed results in these contests. Although the party was able to retain hold of Mexico state and Coahuila, it did so by only narrow margins. The PRI faced considerable losses in Nayarit and Veracruz.

Voters in Mexico state elected Alfredo del Mazo (PRI) with 33.56\% support, followed by Delfina Gómez (MORENA) with 30.78\%. Although the PRI retained control over the state, its performance was much weaker compared to the prior 2011 gubernatorial race. That year, the PRI's Eruviel Ávila Villegas (PRI-PVEM-NA) won with 61.9\% support, with the PRD's Alejandro Encinas Rodríguez (PRD-PT-Convergencia or Convergence Party) at $20.96 \%$ and the PAN's Luis Felipe Bravo Mena (12.28\%) trailing far behind. Despite retaining state control, the 2017 election placed the PRI in a difficult position ahead of the 2018 presidential race. See the Instituto Electoral del Estado de México for the results.

In Coahuila, Miguel Riquelme (PRI) was elected, despite being accused of electoral fraud by Guillermo Anaya (PAN). Riquelme won with $38.9 \%$ support, while Anaya received $36.4 \%$. Allegations of fraud began the morning after the election, when Coahuila's state electoral institute was unable to announce a 
clear winner due to the closeness of the race. In response, Anaya-accompanied by the other candidates, Armando Guadiana (MORENA), Luis Horacio Salinas (independent), and Javier Guerrero (independent)-impugned the electoral process. Their "Coahuila Dignity Front" claimed that the PRI candidate had exceeded campaign spending limits, a formal cause for annulation of the election. However, the Federal Electoral Tribunal (TEPJF) decided on 24 November 2017 that there was not enough evidence to recommend annulling the election and announced that Riquelme could take office, which occurred on 1 December 2017. The PRI won 27 out of 38 municipalities, the PAN six municipalities, with other small parties winning the remainder. Coahuila's state legislature has 25 deputies, with 16 elected by plurality from single-member districts and nine by proportional representation from a single state-wide district. The PRI won seven single-member district deputies and three proportional representation deputies, with the PAN winning six single-member district and three proportional representation deputies, the Party of Democratic Unity of Coahuila two proportional representation deputies, MORENA two proportional representation deputies, and the PRD one proportional representation deputy. The PRI thus retained control of the state. Election data is available from the Instituto Electoral de Coahuila.

In Nayarit, voters elected a new state governor, state legislature (comprised of 18 members elected by plurality from single-member districts and 12 from a single state-wide district elected by proportional representation), and 20 municipal governments. Two main contenders competed in the gubernatorial race: state ruling party Manuel Humberto Cota Jiménez (PRI) (heading a PRI-PVEM-NA coalition) and opposition candidate Antonio Echevarría García (PAN) (heading a PAN-PRD-PT coalition). Echevarría won with $38.66 \%$ support, followed by Cota. The PAN coalition won 15 of 18 single-member district deputies, with the remaining three distributed among the PRI, the PRI coalition, and MORENA. This result contrasted dramatically with 2014 midterm state elections when the PRI won 13 out of 18 districts. The PAN coalition was also a big winner in the 2017 municipal elections, winning 10 out of 20 municipalities. Nayarit thus experienced a shift in partisan control from the PRI to the PAN. Electoral data is available from the Instituto Estatal Electoral de Nayarit.

In Veracruz, 212 municipal governments were elected. The election results gave an advantage to the ruling PAN-PRD coalition, since together these parties won 112 municipal presidencies. A PRI-PVEM coalition won 36 municipal presidencies. The NA won 18 municipalities, MORENA won 17, with remaining municipalities split between the PT, Citizen Movement, and Social Encounter. Data is available from the Organismo Público Local Electoral de Veracruz. 


\section{EXECUTIVE BRANCH}

Most executive branch changes during 2017 were made with an eye to the 2018 presidential race. On 5 January 2017, Peña Nieto announced former Finance Minister Luis Videgaray's return to the cabinet as Foreign Affairs Minister, replacing Claudia Ruiz Massieu. Videgaray initially left the cabinet in 2016 after he organized a widely criticized visit by then presidential candidate Donald J. Trump to Mexico (Partlow 2016). Videgaray's reappointment was made in the hope of improving his image ahead of the PRI's presidential candidate selection process, although low public support for his candidacy led his name to be removed from contention. The president also named María Cristina García Cepeda as Culture Minister (Reséndiz 2017).

On 27 November, José Antonio Meade resigned as Finance Minister in order to register as a competitor for the PRI's presidential candidacy. He was replaced by José Antonio González Anaya, who was director of state oil company PEMEX (Petróleos Mexicanos). José Carlos Treviño replaced Anaya at PEMEX. On 6 December 2017, Education Minister Aurelio Nuño resigned to join Meade's campaign as chief campaign advisor. Mexican Social Security Institute (Instituto Mexicano de Seguridad Social or IMSS) director Mikel Arriola also resigned that day to register as the PRI's candidate for Mexico City governor (Excelsior 2017).

Although not related to the 2018 election, on 30 November Agustín Carstens left his position as governor of the Bank of Mexico (Banxico) to become the general manager of the Bank of International Settlements (BIS). Carstens had originally resigned in July 2017 but later agreed to remain in his post until 30 November due to growing peso devaluation and rising peso volatility. Carstens was first appointed to head the central bank in 2009 (term beginning on 1 January 2010) by Calderón and was reappointed by Peña Nieto in 2015 (term beginning on 1 January 2016) (Milenio 2017).

\section{LEGISLATIVE BRANCH}

During 2017, the PRI continued to enjoy a plurality position in both chambers of congress, as shown in Table 2 and Table 3. Several legislators changed party affiliations in political moves ahead of the 2018 presidential race, including several PAN members who left the party to support Zavala's independent candidacy as well as several PRD members who left to support López Obrador's MORENA campaign (Guzmán and Gutiérrez 2017). ${ }^{2}$

\footnotetext{
Mexico's chamber of deputies is composed of 500 members, with 300 elected by plurality from 300 single-member districts and 200 by proportional representation in five multi-party districts. The senate is composed of 120 members, with 64 elected by plurality from the 32 states (two per state), 32 by the principle of first minority from the 32 states (one per state), and 32 chosen by from a single-nationwide district by proportional representation in a single, nation-wide district.
} 
The new congressional year officially began on 1 September 2017, with the lower chamber then charged with selecting the members of its board of directors. The chamber's board of directors is responsible for directing sessions and determining the relevant committees for reviewing legislation and is thus one of the most powerful committees in congress. However, opposition parties stalled the board selection process. Opposition parties, along with numerous other civil society groups, opposed the government's decision to allow current prosecutor general Raúl Cervantes, a longtime PRI member and former legislator close to Peña Nieto, to continue as attorney general after the office's planned formal separation from the executive branch (Lafuente 2017). Institutional reforms approved in 2014 formally separated the prosecutor general's officeto be renamed the attorney general's office-from the executive branch. The prosecutor general is responsible for prosecuting federal crimes, including corruption, with its lack of formal independence from the executive branch cited as the main reason for its weak initiative in rooting out and prosecuting corruption. After six days of legislative paralysis, members of the lower chamber came to an agreement to appoint the chamber board, to be chaired by Jorge Carlos Ramírez Marín (PRI), in exchange for an agreement to eliminate Cervantes' automatic transfer from prosecutor general to attorney general with the creation of the new attorney general office. Cervantes resigned as prosecutor general in October 2017 (Lafuente 2017, Eurasia Group 2018).

Table 2. Composition of the Chamber of Deputies (Seats)

\begin{tabular}{lccc}
\hline \multicolumn{1}{c}{ Party } & Plurality & $\begin{array}{c}\text { Proportional } \\
\text { RePresentation }\end{array}$ & Total Seats \\
\hline PRI & 155 & 47 & $202(40.4 \%)$ \\
PAN & 55 & 53 & $108(21.6 \%)$ \\
PRD & 28 & 27 & $55(11 \%)$ \\
MORENA & 24 & 23 & $47(9.4 \%)$ \\
PVEM & 21 & 18 & $39(7.8 \%)$ \\
MC & 11 & 10 & $21(4.2 \%)$ \\
NA & 2 & 11 & $13(2.6 \%)$ \\
PES & 1 & 9 & $10(2 \%)$ \\
IND & 1 & 0 & $1(0.2 \%)$ \\
No Party & 2 & 2 & $4(0.8 \%)$ \\
Total & 300 & 200 & $500(100 \%)$ \\
\hline
\end{tabular}

Source: LXIII Legislatura, Cámara de Diputados 
Table 3. Composition of the Senate (Seats)

\begin{tabular}{cc}
\hline Party & Seats \\
\hline PRI & $55(42.9 \%)$ \\
PAN & $34(26.6 \%)$ \\
PT & $19(14.8 \%)$ \\
PRD & $7(5.5 \%)$ \\
PVEM & $5(3.9 \%)$ \\
No Party & $8(6.3 \%)$ \\
Total & $128(100 \%)$ \\
\hline
\end{tabular}

Source: LXIII Legislatura, Senado de la República

\section{US-Mexico Relations}

US-Mexico relations were under considerable strain during 2017. Throughout his 2016 campaign, Donald J. Trump frequently discussed US-Mexico relations. On immigration from Mexico, Trump stated: "When Mexico sends its people, they are not sending their best" (Time 2015) and "I will immediately terminate President Obama's illegal executive order on immigration" (Time 2015). On building a border wall with Mexico to stem illegal immigration: "I will build a great, great wall on our southern border" (Time 2015). On preventing job losses to Mexico: "I'll bring back our jobs from China, from Mexico, from Japan...I'1l bring back our jobs, and I'll bring back our money" (Time 2015). On NAFTA: "I'm going to tell our NAFTA partners that I intend to immediately renegotiate the terms of that agreement...If they do not agree to renegotiation, then I will submit notice under Article 2205 of the NAFTA agreement that America intends to withdraw from the deal" Trump (2015).

The tenor of Trump's statements colored Mexican citizens' views about the US. Favorability ratings of the US and confidence in the US president shrank considerably in 2017 (Pew Research Center 2017), as shown in Figure 13. Buoyed by negative public opinion toward the US, Mexican Peña Nieto stated on 2 September 2017 that "The relationship with the new government of the United States, like any other nation, must be based on irrevocable principles: sovereignty, defense of the national interest and protection of our migrants" and that "We will not accept anything that goes against our national dignity" (Esposito and Daniel 2017).

Formal NAFTA negotiations kicked-off on 16 August 2017, with five rounds scheduled for 2017 and additional rounds for 2018 (Office of the United States Trade Representative) (Table 4). The Mexican government began 2017 with a conciliatory attitude toward the US, due to fears that Trump would act upon his threats to scrap NAFTA. However, as the year progressed, the Mexican government came to view these threats as a ploy to "gain the upper 
hand" during NAFTA negotiations, leading the Mexican government to take a harder-line position during trade negotiations later in the year (Ljunggren 2017; McDonnell 2017). Mexico's increasingly hardline tactics toward the US, alongside the rising chance that NAFTA-skeptic Andrés Manuel López Obrador (MORENA) would win the 2018 Mexican presidential race and derail NAFTA negotiations altogether, encouraged a shift in the US tactics and swifter progress in response (Ljunggren 2017; McDonnell 2017).

Figure 13. Mexican Attitudes Toward the US

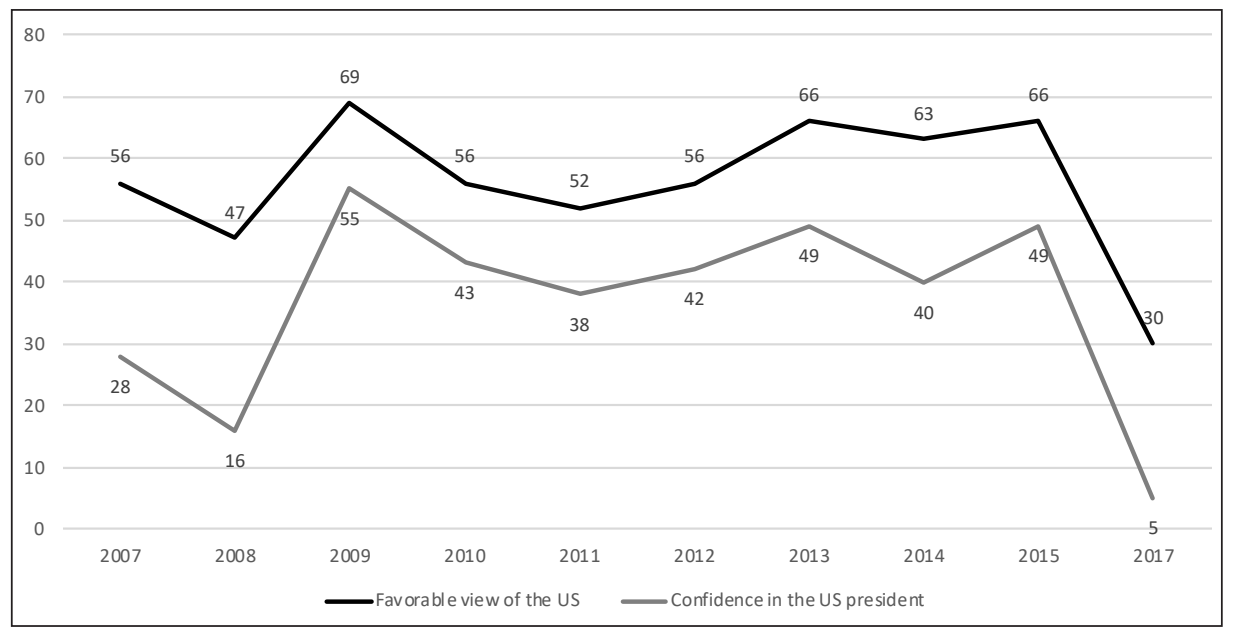

Source: Pew Research Center (2017)

Table 4. NAFTA Negotiation Rounds

\begin{tabular}{lll}
\hline \multicolumn{1}{c}{ Round } & \multicolumn{1}{c}{ DATE } & \multicolumn{1}{c}{ VeNUE } \\
\hline First Round & 16- 20 August 2017 & Washington, D.C., US \\
Second Round & 1 - 5 September 2017 & Mexico City, Mexico \\
Third Round & 23- 27 September 2017 & Ottawa, Canada \\
Fourth Round & 11- 15 October 2017 & Washington, D.C., US \\
Fifth Round & 15- 21 November 2017 & Mexico City, Mexico \\
Sixth Round & 22 - 29 January 2018 & Montreal, Canada \\
Seventh Round & 25 February - 5 March 2018 & Mexico City, Mexico \\
Unofficial Round* & 6- 8 April 2018 & Washington, D.C., US \\
Eighth Round & 9 - 16 April 2018 & Washington, D.C., US \\
\hline
\end{tabular}

*High level meetings between Mexican Economy Minister Ildefonso Guajardo, Canadian Minister of Foreign Affairs Chrystia Freeland, US Trade Representative Robert Lighthizer.

Source: Office of the United States Trade Representative 
As shown in in Table 5, as of March 2018 considerable progress had been made on individual NAFTA chapters, although several controversial chapters still remained unresolved. Among those, the US government demanded "rules of origin" requirements for automotive goods to qualify for free trade (Reuters Staff 2017). The US government proposed seasonal tariffs on agricultural exports from Mexico, which is able to produce year-round, to protect US producers who only enjoy seasonal production (Reuters Staff 2017). The US proposed that Mexican and Canadian government procurement processes be opened to US companies, even though the US also sought to promote its "Buy America" policy in the US's own government procurement processes (Reuters Staff 2017). The US government also proposed a "sunset clause," whereby NAFTA would be re-evaluated every five years and re-signed (Reuters Staff 2017). These were among the more controversial items that were still under negotiation at the end of 2017 (and mid 2018). By late 2017 and mid 2018, however, the US softened stances on these pending issues in the interest of reaching agreement before the July 2018 Mexican presidential election, although this did not occur (Eurasia Group 2018, Reuters Staff 2017).

Table 5: NAFTA Progress, as of March 2018

\begin{tabular}{|c|c|}
\hline CHAPTER & Овјестіvе \\
\hline \multicolumn{2}{|l|}{ Resolved } \\
\hline $\begin{array}{l}\text { Small and medium } \\
\text { enterprises }\end{array}$ & Improve exports and integration into supply chains \\
\hline Competition policy & $\begin{array}{l}\text { Addressing monopolies and state-owned/controlled } \\
\text { enterprises }\end{array}$ \\
\hline Anti-corruption policies & $\begin{array}{l}\text { Transparency in laws, due process in legal cases, and } \\
\text { integrity among public officials }\end{array}$ \\
\hline Transparency & Transparency in investor-state arbitration procedures \\
\hline Regulatory practices & $\begin{array}{l}\text { Increased customs cooperation and improved cross- } \\
\text { border movement of goods }\end{array}$ \\
\hline $\begin{array}{l}\text { Sanitary and } \\
\text { phytosanitary measures }\end{array}$ & Improve food safety standards \\
\hline \multicolumn{2}{|l|}{ In Progress } \\
\hline Digital trade & Improve e-commerce integration \\
\hline Trade facilitation & $\begin{array}{l}\text { Streamline customs and other cargo-processing } \\
\text { procedures }\end{array}$ \\
\hline $\begin{array}{l}\text { Intellectual property } \\
\text { rights }\end{array}$ & Improve protections \\
\hline Gender standards & Promote gender equality \\
\hline Labor standards & Strengthen labor rights and enforcement \\
\hline Environmental standards & Improved environmental standards \\
\hline
\end{tabular}




\begin{tabular}{|c|c|}
\hline CHAPTER & Овјестіvе \\
\hline \multicolumn{2}{|l|}{ In Progress } \\
\hline Energy & $\begin{array}{l}\text { Improve market-based integration of Canadian, } \\
\text { Mexican, US energy markets }\end{array}$ \\
\hline Telecommunications & $\begin{array}{l}\text { Improve regulatory transparency and market } \\
\text { competition }\end{array}$ \\
\hline \multicolumn{2}{|l|}{ Unresolved } \\
\hline Auto rules of origin & $\begin{array}{l}\text { US proposed increased regional content rules of origin } \\
\text { for automotive goods }\end{array}$ \\
\hline Seasonal restrictions & $\begin{array}{l}\text { US proposed seasonal protections for US agricultural } \\
\text { producers against year-round Mexican producers }\end{array}$ \\
\hline Sunset clause & US proposed reevaluation of NAFTA every five years \\
\hline Dispute settlement & $\begin{array}{l}\text { US proposed changes to reform dispute settlement } \\
\text { procedures, so that firms receive "fair and equitable" } \\
\text { treatment by foreign governments }\end{array}$ \\
\hline Government procurement & $\begin{array}{l}\text { US proposed opening government procurement to } \\
\text { NAFTA member bids }\end{array}$ \\
\hline $\begin{array}{l}\text { Canadian supply } \\
\text { management }\end{array}$ & $\begin{array}{l}\text { US proposed elimination of non-tariff barriers to US } \\
\text { agricultural exports to Canada }\end{array}$ \\
\hline
\end{tabular}

Source: Eurasia Group (2018) and Reuters Staff (2017)

\section{CONCLUSION}

To be sure, 2017 was a year of economic, social, and thus political uncertainty for Mexico, raising the disadvantages for the incumbent PRI ahead of the 1 July 2018 presidential elections. Poor economic performance, social friction, rising violence, corruption scandals, and conflictual US relations raised the challenges for the ruling PRI ahead of the election. The ruling party's biggest opponents, Andrés Manuel López Obrador (MORENA) and Ricardo Anaya (PAN), used the nation's economic and social woes to construct election campaigns criticizing the structural economic reforms carried out by the Peña Nieto administration. These political leaders also criticized unprecedented and endemic corruption by PRI officials. Thanks to economic decline, rising violence, and corruption scandals of concern to voters, the PRI faced a serious incumbent party disadvantage heading into the 2018 election, with Andrés Manuel López Obrador (MORENA) easily prevailing.

\section{REFERENCES}

Agren, David. 2017, 13 April. "Mexico's Former Governors Are Being Busted for Bad Behavior. So Some Are Choosing to Hide." Retrieved on 1 April 2018 from https:/ /www.washingtonpost.com/news/worldviews/wp/2017/04/13/a-mexican-ex-governor-wasarrested-this-week-but-there-are-more-still-hiding-out/?utm_term=.1a9b73a2c839. 
Ahmed, Azam, Marina Franco, and Henry Fountain. 2017, 23 September. "Luck, Not Tougher Building Standards, Spared Mexico in Quake." Retrieved on 1 April 2018 from https://www.nytimes.com/2017/09/23/world/americas/mexico-city-earthquake-buildings.html.

Animal Político. 2016, 14 September. "El nivel de deuda pública está en rojo, y no se ha traducido en crecimiento: \#SemáforoEconómico." Retrieved on 1 April 2018 from http:/ / www.animalpolitico.com/2016/09/el-nivel-de-deuda-publica-esta-en-rojo-y-no-se-ha-traducido-en-crecimiento-semaforoeconomico/?platform=hootsuite.

Animal Político. 2017a, 15 April. "Detienen a Javier Duarte en Guatemala." Retrieved on 1 April 2018 from https://www.animalpolitico.com/2017/04/detienen-javier-duarte-guatemala/.

Animal Político. 2017b, 2 January. "El poder adquisitivo de los mexicanos se ha reducido 11\% en el sexenio de Peña." Retrieved on 1 April 2018 from https://www.animalpolitico. com/2017/01/adquisitivo-poder-mexicanos-pena/.

Animal Político. 2017c, 30 August. "La pobreza baja 3.47\% en México, pero la mitad de la población sigue siendo pobre." Retrieved on 1 April 2018 from https:/ /www.animalpolitico.com/2017/08/pobreza-mexico-reswdujo-coneval/.

Associated Press. 2017, 9 October. "Outdated Construction Methods Caused Most Building Collapses in Mexico Earthquake, Engineers Say." Retrieved on 1 April 2018 from https:/ / www.nbcnews.com/news/world/outdated-construction-methods-caused-most-building-collapses-mexico-earthquake-engineers-n809146.

Banco de México. n.d. Retrieved on 1 April 2018 from http://www.banxico.org.mx.

Banco de México. 2018. Quarterly Report, October-December 2017 (Executive Summary). Banco de México.

Barrientos del Monte, Fernando, and Daniel Añorve Añorve. 2014. "México 2013: Acuerdos, Reformas y Descontento." Revista de Ciencia Política 34 (1): 221-47.

Casillas, Gabriel. 2017, September 26. "Reflexiones sobre el temblor." Retrieved on 1 April 2018 from September 2017. http://www.elfinanciero.com.mx/opinion/gabriel-casillas/reflexiones-sobre-el-temblor.

Cattan, Nacha. 2017, 7 August. “Unpopular Ruling Party Scrambles to Hold onto Power in Mexico." Retrieved on 1 April 2018 from https://www.bloomberg.com/news/articles /2017-08-07/unpopular-ruling-party-scrambles-to-hold-onto-power-in-mexico.

Centro de Estudios de las Finanzas Públicas (CEFP). 2018. Obligaciones Financieras de las Entidades Federativas de México, al Cuarto Trimestre de 2017. Ciudad de México: Centro de Estudios de las Finanzas Públicas (CEFP), Cámara de Diputados, LXIII Legislatura.

Consulta Mitofsky. 2018. Evaluación 21 Trimestres de gobierno de Enrique Peña Nieto.

Daen, Arturo, and Liz Padilla. 2017, 2 January. "Bloqueos y toma de gasolinerías: así inició el 2017 por alza a los precios del combustible." Retrieved on 1 April 2018 from https: / / www.animalpolitico.com/2017/01/compras-panico-colapsaron-gasolineras-alistan-protestas-alza-combustibles/.

de Córdoba, José, and Santiago Pérez. 2016, 11 August. "Mexico's President Faces New Scrutiny." Retrieved on 1 April 2018 from http://www.wsj.com/articles/mexico-president-faces-new-scrutiny-1470965694.

Diaz, Lizbeth. 2017, 6 October. “Fourth Ex-governor from Mexico's PRI Arrested on Corruption Charges." Retrieved on 1 April 2018 from https://www.reuters.com/article/ us-mexico-corruption / fourth-ex-governor-from-mexicos-pri-arrested-on-corruption-charges-idUSKBN1CB2WQ.

Esposito, Anthony, and Frank Jack Daniel. 2017, 2 September. “NAFTA Negotiators Seek to Enshrine Mexico's Energy Reforms." Retrieved on 1 April 2018 from https://www. reuters.com/article/us-trade-nafta/nafta-negotiators-seek-to-enshrine-mexicos-energy-reforms-idUSKCN1BD0TS.

Eurasia Group. 2018. A NAFTA Deal Is Gaining Momentum, But Tight Deadline Remains A Real Risk. 
Excelsior. 2017, 27 November. “Estos son los cambios de Peña Nieto en su gabinete." Retrieved on 1 April 2018 from http:/ /www.excelsior.com.mx/nacional/2017/11/27/1203863.

Foer, Franklin. 2017, May. " Mexico's Revenge." Retrieved on 1 April 2018 from https:/ / www. theatlantic.com/magazine/archive/2017/05/mexicos-revenge/521451/.

Freidenberg, Flavia, and Francisco Javier Aparicio. 2016. "México 2015: Entre la fragmentación partidista y el descontento ciudadano." Revista de Ciencia Política 36 (1): 219-38.

García, Carina, and Misael Zavala, 2017, 15 December. "Registran coalición Juntos Haremos Historia." Retrieved on 1 April 2018 from http://www.eluniversal.com.mx/elecciones-2018/registran-coalicion-juntos-haremos-historia.

Gillespie, Patrick. 2017, 22 November. "Mexico to raise minimum wage...to $\$ 4.70$ a day." CNN Money. http://money.cnn.com/2017/11/22/news/economy/mexico-minimum-wage/index.html.

González, Héctor, and Juan Pablo Reyes. 2017, 10 April. "Cae Yarrington; fue detenido en Italia: PGR." Retrieved on 1 April 2018 from http://www.excelsior.com.mx/nacio$\mathrm{nal} / 2017 / 04 / 10 / 1156879$.

Guzmán Calafell, Javier. 2018. "Mexico's Monetary Policy: Outlook and Challenges." 4th BBVA Latin America Local Markets Conference, London, UK, 15 January 2018.

Guzmán, Susana, and Héctor Gutiérrez. 2017, 29 December. "Desbandadas y rupturas, el costo que pagan PAN y PRD por aliarse." Retrieved on 1 April 2018 from http:/ /www. elfinanciero.com.mx/nacional/desbandadas-y-rupturas-el-costo-que-pagan-pan-yprd-por-aliarse.

Instituto Electoral de Coahuila. Accessed on 1 April 2018 from http://www.iec.org.mx/v1/.

Instituto Estatal Electoral de Nayarit. Accessed on 1 April 2018 from http://www.ieen.org. $\mathrm{mx} /$.

Instituto Estatal Electoral del Estado de México. Retrieved on 1 April 2018 from http:/ /www. ieem.org.mx.

INEGI (Instituto Nacional de Estadística Geografía e Informática). n.d. "Banco de Información Económica (BIE)." Retrieved on 1 April 2018 from http://www.inegi.org.mx/ sistemas/bie/.

INEGI (Instituto Nacional de Estadística Geografía e Informática). 2017. Encuesta Nacional de Victimización y Percepción sobre Seguridad Pública (ENVIPE) 2017. Instituto Nacional de Estadística y Geografía (INEGI).

Lafuente, Javier. 2017, 17 October. "Raúl Cervantes renuncia al cargo de procurador general de México." Retrieved on 1 April 2018 from https://elpais.com/internacional/2017/10/16/mexico/1508166979_295991.html.

Linthicum, Kate. 2016, 2 September. “Even Before Trump's Visit, Peña Nieto Was Mexico's Least Popular President Ever. Too Late to Change That." Retrieved on 1 April 2018 from http://www.latimes.com/world/mexico-americas/la-fg-mexico-pena-nieto20160830-snap-story.html.

Ljunggren, Gabriel Stargardter and David. 2017, 23 August. "Mexico, Canada dismiss Trump threats to scrap NAFTA trade pact." Retrieved on 1 April 2018 from https:/ / www.reuters.com/article/us-usa-trump-nafta-mexico/mexico-canada-dismiss-trump-threatsto-scrap-nafta-trade-pact-idUSKCN1B31H1.

LXIII Legislatura, Cámara de Diputados. Accessed on 1 April 2018 from http:/ / sitl.diputados. gob.mx/LXIII_leg/info_diputados.php.

LXIII Legislatura, Senado de la República. Accessed on 1 April 2018 from http:/ /www.senado.gob.mx.

Malkin, Elisabeth. 2017, 19 April. "Corruption at a Level of Audacity 'Never Seen in Mexico.'” Retrieved on 1 April 2018 from https: / /www.nytimes.com/2017/04/19/world/americas/in-mexico-mounting-misdeeds-but-governors-escape-justice.html.

Márquez, Javier. 2018. "Poll of Polls." Oraculus: Todo Elecciones. Retrieved on 1 April 2018 from http://oraculus.mx/poll-of-polls/. 
McDonnell, Patrick J. 2017, 31 August. "Mexico signals tougher stance on NAFTA, may pull out of talks if Trump moves to scrap deal." Retrieved on 1 April 2018 from http:// www.latimes.com/world/mexico-americas/la-fg-mexico-nafta-20170831-story.html.

Milenio. 2017, 20 November. "Agustín Carstens dice adiós al Banco de México." Retrieved on 1 April 2018 from http://www.milenio.com/negocios/agustin-carstens-ultimo-dia-banxico-banco-mexico-peso-bis-pagos-internacionales_0_1076292532.html.

Montes, Rafael, Selene Flores, and Omar Brito. 2018, 18 February. "Anaya asume candidatura presidencial del Frente." Retrieved on 1 April 2018 from http://www.milenio. com/elecciones-mexico-2018/ricardo-anaya-candidato-presidencia-frente-por-mexico-frente-pan-prd-mc_0_1124287666.html.

Nación 321, 2018,2 January. “Esto fue lo que los partidos donaron a los damnificados." Retrieved on 1 April 2018 from http:/ / www.nacion321.com/partidos/esto-fue-lo-que-los-partidos-donaron-a-los-damminifcados

Office of the United States Trade Representative. Accessed on 1 April 2018 from https:/ /ustr. gov.

Organismo Público Local Electoral de Veracruz. Accessed on 1 April 2018 from http:/ /www. oplever.org.mx.

OECD (Organization for Economic Cooperation and Development). 2017. "Toward a Stronger and More Inclusive Mexico: An Assessment of Recent Policy Reforms." In Better Policies Series. Paris and Mexico City: Organization for Economic Cooperation and Development (OECD).

Parametría. 2017. Encuestas Sismo 19-SEP-2017 y Medidas de Protección Civil.

Partlow, Joshua. 2016, 2 September. "Inside Mexico's Bizarre Decision to Invite Trump." Retrieved on 1 April 2018 from https://www.washingtonpost.com/world/the_americas/the-behind-the-scenes-skirmishing-that-resulted-in-mexicos-invitation-totrump/2016/09/02/2a02037a-1288-4c4c-9877-135f098e7905_story.html?utm_term=. cb6ab8015f09.

Pew Research Center. 2017. "Spring 2017 Global Attitudes Survey." Retrieved on 1 April 2018 from http://www.pewresearch.org/fact-tank/2017/07/17/9-charts-on-how-theworld-sees-trump/ft_17-07-17_trumpinmexico/.

Pskowski, Martha, and David Adler. 2017, 13 October. "6,000 Complaints ... Then the Quake: The Scandal Behind Mexico City's 225 Dead." Retrieved on 1 April 2018 from https: / / www.theguardian.com/cities/2017/oct/13/complaints-earthquake-scandal-mexico-city-dead-construction-collapse.

Reforma. 2016. "Disculpa de EPN." Accessd on 1 April 2018 from http:/ / gruporeforma-blogs. com/encuestas/?s=Disculpa.

Reséndiz, Francisco, 2018, 19 January. "Avala INE nombre de coalición 'Todos por México' de PRI, PVEM y Nueva Alianza." Retrieved on 1 April 2018 from http:/ /www.eluniversal.com.mx/elecciones-2018/avala-ine-nombre-de-coalicion-todos-por-mexicode-pri-pvem-y-nueva-alianza.

Reséndiz, Francisco. 2017, 5 January. “Anuncia Peña Nieto cambios en el gabinete." Retrieved on 1 April 2018 from http://www.eluniversal.com.mx/articulo/nacion/politi$\mathrm{ca} / 2017 / 01 / 5 /$ anuncia-pena-nieto-cambios-en-el-gabinete.

Reuters, 2017, 1 September. "Factbox: Key Issues in the NAFTA Renegotiations." Retrieved on 1 April 2018 from https://www.reuters.com/article/us-trade-nafta-factbox/factbox-key-issues-in-the-nafta-renegotiations-idUSKCN1BC5H6.

Secretaría de Hacienda y Crédito Pública (SHCP). Retrieved on 1 April 2018 from http:// www.shcp.gob.mx.

Secretariado Ejecutivo del Sistema Nacional de Seguridad Pública. 2018. Cifras de homicidio doloso, secuestro, extorsión y robo de vehículos 1997-2017. Secretaría de Gobernación.

Sholchet, Catherine E. 2017, 6 January. "El aumento del precio de la gasolina provoca protestas y saqueos en México." Retrieved on 1 April 2018 from http://cnnespanol.cnn. $\mathrm{com} / 2017 / 01 / 06 /$ el-aumento-del-precio-de-la-gasolina-provoca-protestas-y-saqueos-en-mexico/. 
Time. 2015, 16 June. "Here's Donald Trump's Presidential Announcement Speech." Retrieved on 1 April 2018 from http://time.com/3923128/donald-trump-announcement-speech/.

Transparency International. n.d. "Corruption Perception Index." Retrieved on 1 April 2018 from www.transparency.org/cpi.

Trump, Donald J. 2015. Declaring American Economic Independence. Retrieved on 1 April 2018 from https://assets.donaldjtrump.com/DJT_DeclaringAmericanEconomicIndependence.pdf.

Ureste, Manu, and Ernesto Aroche. 2017, 19 October. "Lo que el \#19S nos dejó: las víctimas, daños y damnificados en México." Retrieved on 1 April 2018 from https:/ / www.animalpolitico.com/2017/10/cifras-oficiales-sismo-19s/.

Allyson Lucinda Benton is a professor in the Political Studies Division at the Centro de Investigación y Docencia Económicas (CIDE) in Mexico City. Her research interests include the impact of politics of subnational fiscal policy as well as on the impact of politics on financial markets. She has published research in a variety of academic journals, with can be found on www.allysonbenton.com. She can be reached at allyson.benton@cide.edu

Edwin Atilano Robles is a doctoral candidate in Political Science at the Centro de Investigación y Docencia Económicas (CIDE), Mexico City. His research interests include the political economy of authoritarian systems, formal modelling, and quantitative methods. His current research focuses on the politics of income redistribution in authoritarian regimes. He can be reached at edwin.atilano@ alumnos.cide.edu 


\section{APPENDIX}

Figure 1: Gross Fixed Investment in Mexico

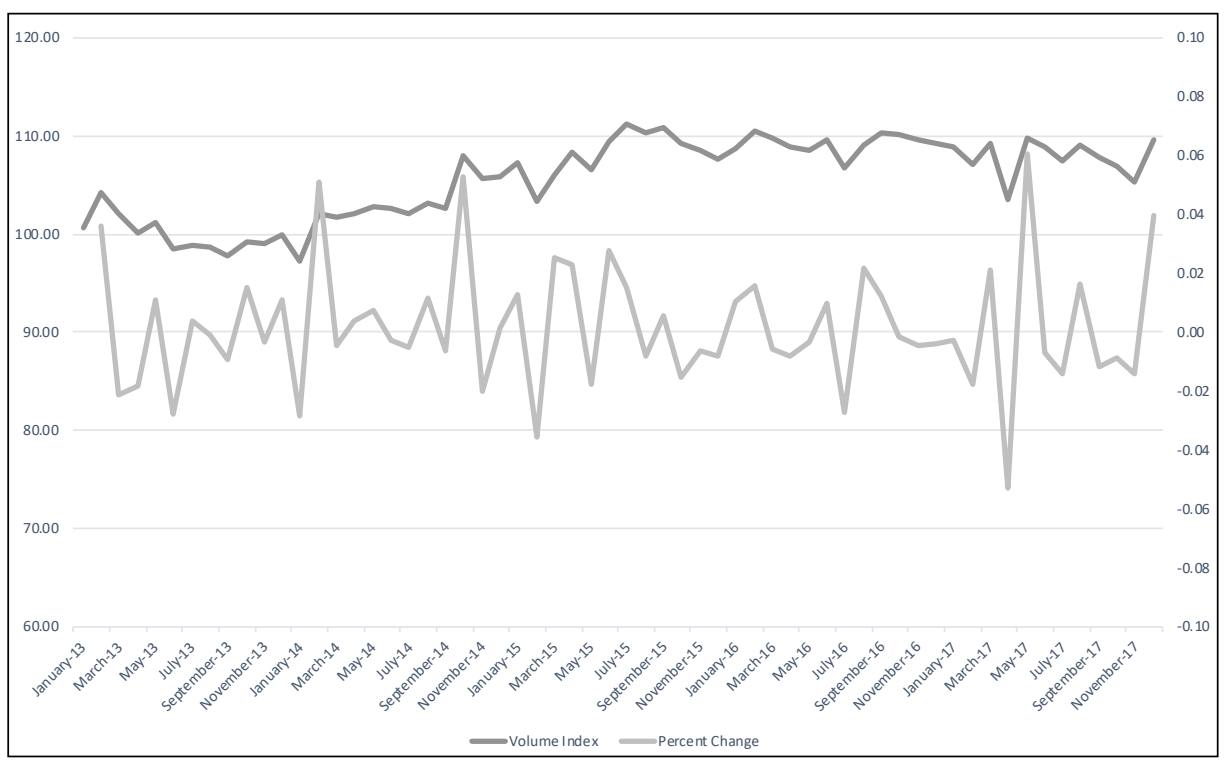

Source: Banco de México .

Figure 2: Global Economic Activity in Mexico

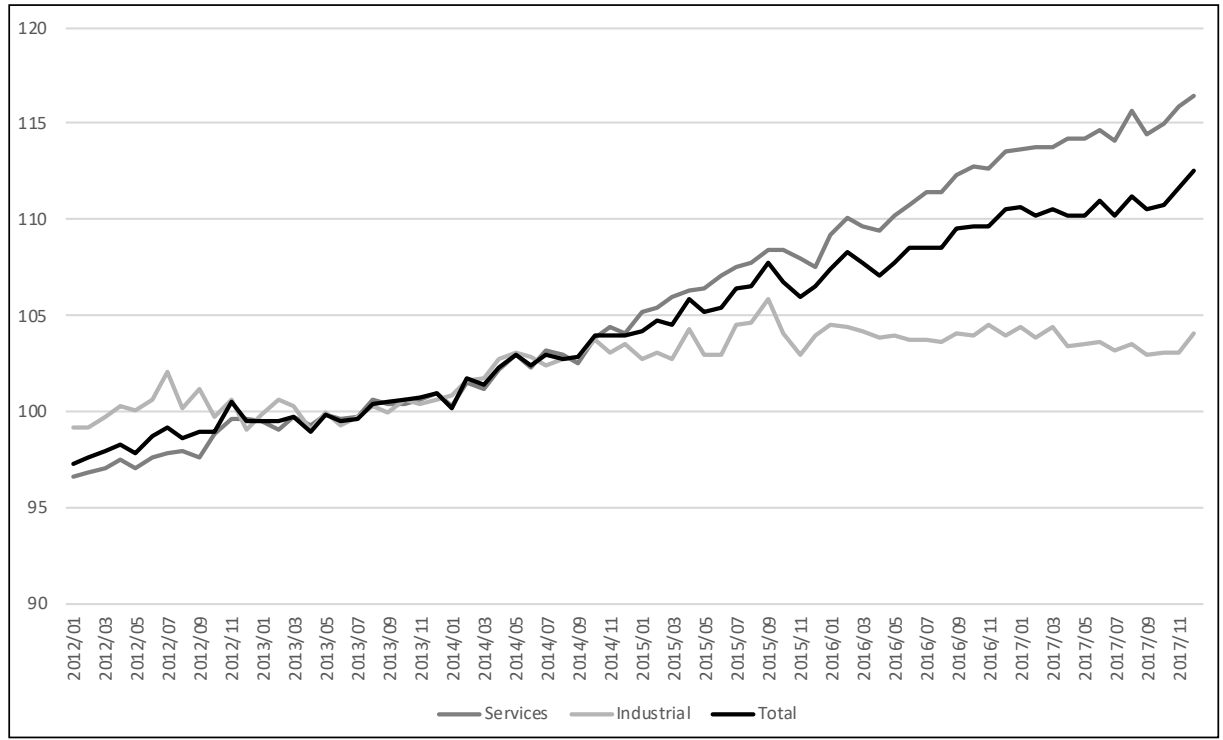

Source: Instituto Nacional de Estadística Geografía e Informática (INEGI) . 
Figure 3: Per Capita State and Municipal Debt

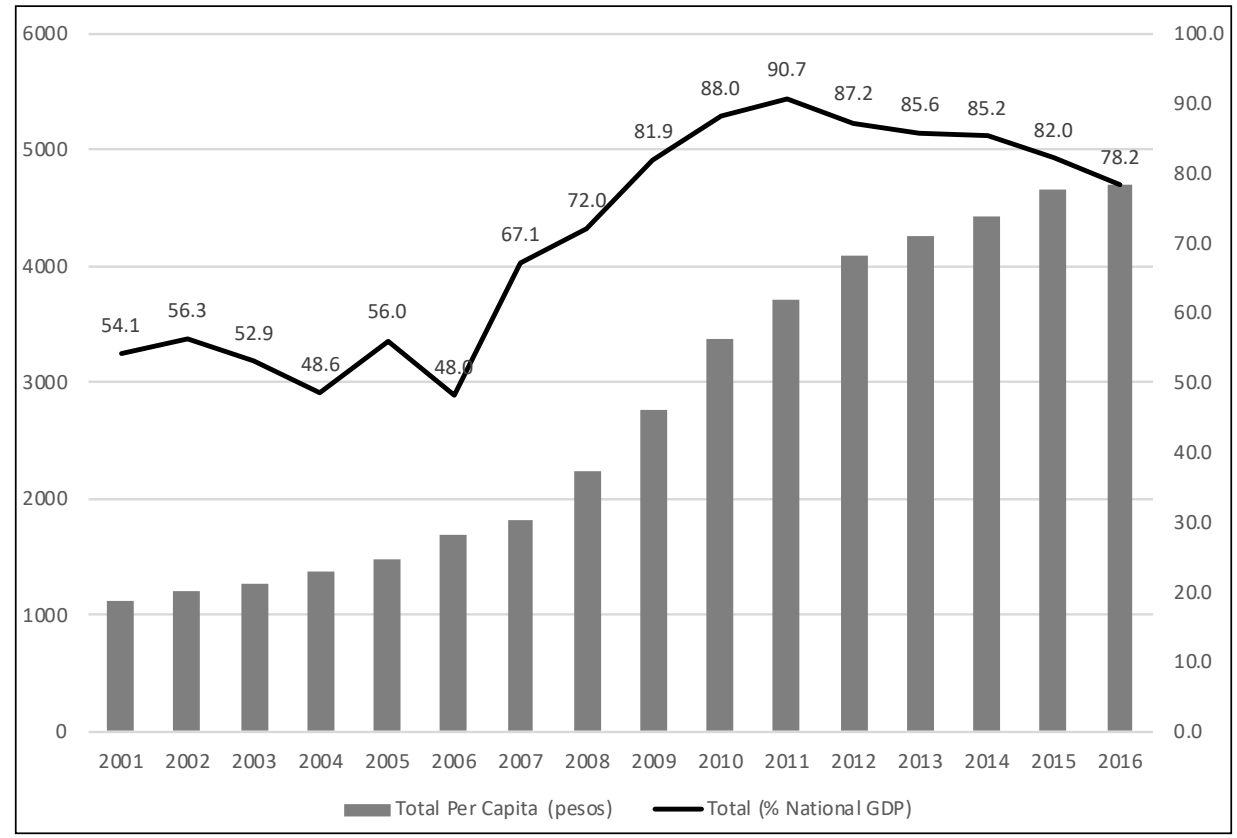

Source: Centro de Estudios de las Finanzas Públicas (CEFP) (2018) 